\title{
The response of soil microbial communities to variation in annual precipitation depends on soil nutritional status in an oligotrophic desert
}

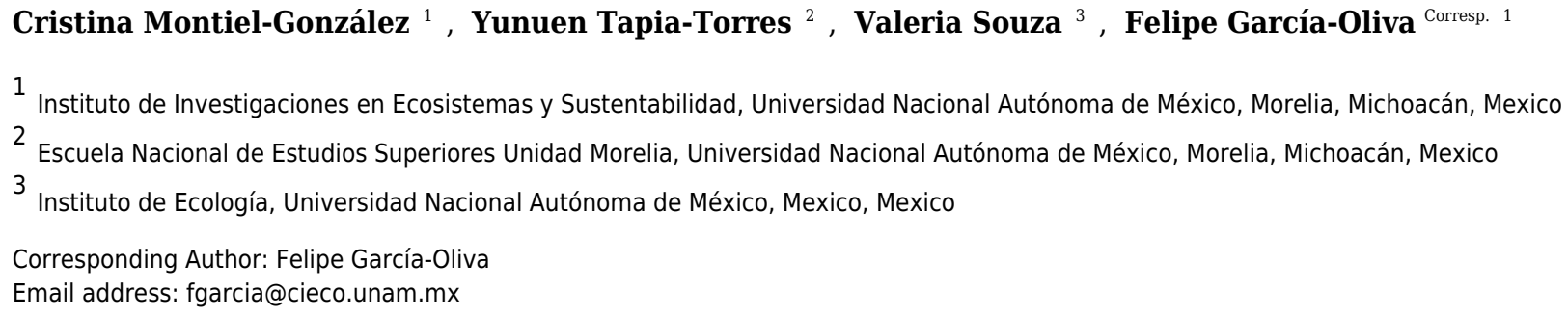

Background. Soil microbial communities (SMC) play a central role in the structure and function of desert ecosystems. However, the high variability of annual precipitation could results in the alteration of SMC and related biological processes depending on soil water potential. The nature of the physiological adjustments made by SMC in order to obtain energy and nutrients remains unclear under different soil resource availabilities in desert ecosystems. In order to examine this dynamic, the present study examined the effects of variation in annual precipitation on physiological adjustments by the SMC across two vegetation-soil systems of different soil organic matter input in an oligotrophic desert ecosystem. Methods. We collected soil samples in the Cuatro Ciénegas Basin (Mexico) under two vegetation covers: rosetophylous scrub (RS) and grassland (G), that differ in terms of quantity and quality of organic matter. Collections were conducted during the years 2011, 2012, 2013 and 2014, over which a noticeable variation in the annual precipitation occurred. The ecoenzymatic activity involved in the decomposition of organic matter, and the concentration of dissolved, available and microbial biomass nutrients, were determined and compared between sites and years. Results. In 2011, we observed differences in bacterial taxonomic composition between the two vegetation covers. The lowest values of dissolved, available and microbial nutrients in both cover types were found in 2012. The G soil showed higher values of dissolved and available nutrients in the wet years. Significant positive correlations were detected between precipitation and the ratios Cmic:Nmic and Cmic:Pmic in the RS soil and Cmic:Pmic and Nmic:Pmic in the G soil. The slopes of the regression with $\mathrm{Cmic}$ and $\mathrm{Nmic}$ were higher in the $\mathrm{G}$ soil and lower in the RS soil. Moreover, the SMC under each vegetation cover were co-limited by different nutrients and responded to the sum of water stress and nutrient limitation. Discussion. Soil community within both sites (RS and G) may be vulnerable to drought. However, the 
community of the site with lower resources (RS) is well adapted to acquire $P$ resources by ecoenzyme upregulation during years with adequate precipitation, suggesting that this community is resilient after drought occurs. Under the Global Climate Change scenarios for desert ecosystems that predict reduced annual precipitation and an increased intensity and frequency of torrential rains and drought events, the soil microbial communities of both sites could be vulnerable to drought through $\mathrm{C}$ and $\mathrm{P}$ co-limitation and reallocation of resources to physiological acclimatization strategies in order to survive. 
1 The response of soil microbial communities to variation in annual precipitation depends on soil

2 nutritional status in an oligotrophic desert

3

4 Cristina Montiel-González ${ }^{\mathrm{a}}$, Yunuen Tapia-Torres ${ }^{\mathrm{b}}$, Valeria Souza ${ }^{\mathrm{c}}$ and Felipe García-Oliva ${ }^{\mathrm{a}^{*}}$.

5

6 anstituto de Investigaciones en Ecosistemas y Sustentabilidad, Universidad Nacional Autónoma

7 de México, Morelia, Michoacán, México.

8 cmontiel@cieco.unam.mx; fgarcia@cieco.unam.mx

9

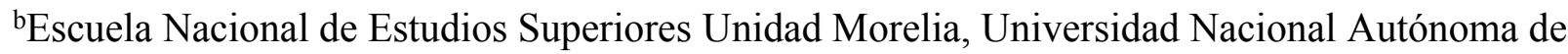
11 México, Morelia, Michoacán, México.

12 ytapia@enesmorelia.unam.mx

'Instituto de Ecología, Departamento de Ecología Evolutiva, Universidad Nacional Autónoma de 15 México, México DF, México. souza@unam.mx

17

*Corresponding autor: Felipe García-Oliva. Instituto de Investigaciones en Ecosistemas y Sustentabilidad, Universidad Nacional Autónoma de México. Antigua carretera a Pátzcuaro No. 8701, col. Ex Hacienda de San José de la Huerta, CP 58190, Morelia, Michoacán, México.

21 fgarcia@cieco.unam.mx, +52 4433222715. 
24 Abstract

25 Background. Soil microbial communities (SMC) play a central role in the structure and function of desert ecosystems. However, the high variability of annual precipitation could results in the alteration of SMC and related biological processes depending on soil water potential. The nature of the physiological adjustments made by SMC in order to obtain energy and nutrients remains unclear under different soil resource availabilities in desert ecosystems. In order to examine this dynamic, the present study examined the effects of variation in annual precipitation on physiological adjustments by the SMC across two vegetation-soil systems of different soil organic matter input in an oligotrophic desert ecosystem.

Methods. We collected soil samples in the Cuatro Ciénegas Basin (Mexico) under two vegetation covers: rosetophylous scrub (RS) and grassland (G), that differ in terms of quantity and quality of organic matter. Collections were conducted during the years 2011, 2012, 2013 and 2014 , over which a noticeable variation in the annual precipitation occurred. The ecoenzymatic activity involved in the decomposition of organic matter, and the concentration of dissolved, available and microbial biomass nutrients, were determined and compared between sites and years.

Results. In 2011, we observed differences in bacterial taxonomic composition between the two vegetation covers. The lowest values of dissolved, available and microbial nutrients in both cover types were found in 2012. The G soil showed higher values of dissolved and available nutrients in the wet years. Significant positive correlations were detected between precipitation and the ratios Cmic:Nmic and Cmic:Pmic in the RS soil and Cmic:Pmic and Nmic:Pmic in the G soil. The slopes of the regression with Cmic and Nmic were higher in the G soil and lower in the 
46 RS soil. Moreover, the SMC under each vegetation cover were co-limited by different nutrients

47 and responded to the sum of water stress and nutrient limitation.

48 Discussion. Soil community within both sites (RS and G) may be vulnerable to drought.

49 However, the community of the site with lower resources (RS) is well adapted to acquire P

50 resources by ecoenzyme upregulation during years with adequate precipitation, suggesting that

51 this community is resilient after drought occurs. Under the Global Climate Change scenarios for

52 desert ecosystems that predict reduced annual precipitation and an increased intensity and

53 frequency of torrential rains and drought events, the soil microbial communities of both sites

54 could be vulnerable to drought through $\mathrm{C}$ and $\mathrm{P}$ co-limitation and reallocation of resources to

55 physiological acclimatization strategies in order to survive. 
58

59

60

61

62

63

64

65

66

67

\section{Introduction}

In desert ecosystems, precipitation is highly variable among years and this variability has increased in recent years due to the effect of Global Climate Change (GCC) (Bell et al. 2014; IPCC 2013). The scenarios derived from GCC models for desert ecosystems predict reduced annual precipitation, as well as increases in the annual precipitation variability by the end of the 21 st century, including an increase in the frequency and intensity of both torrential rain and drought events (Holmgren et al. 2006; IPCC 2013). The high variability of annual precipitation projected for desert ecosystems could alter biological processes dependent on soil water potential, as is the case with the processes related to soil organic matter (SOM) decomposition (D'Odorico \& Bhattachan 2012; Fay et al. 2008; Thomey et al. 2011). For example, enzymatic activity stimulated by rainfall in desert ecosystems may result in most of the total annual mineralization that occurs in desert soils (Manzoni et al. 2012). However when soil water potential decreases, the metabolic activity of most soil microbial species is reduced, and thus a decline in nutrient mineralization can occur. Additionally, soil drying reduces enzymatic activity and microbial mobility, which reduces substrate supply for the decomposers (Henry 2013; Manzoni et al. 2012). Likewise, studies in a semiarid region in New Mexico (Cregger et al. 2012) and in the Chihuahuan Desert (Bell et al. 2009; Bell et al. 2014) showed that the high precipitation variability significantly altered the structure of the soil microbial community, mainly due to a change in the fungal/bacterial ratio and consequently altered microbial community functional dynamics.

Microbial communities play a central role in the structure and functioning of desert ecosystems since they represent an important pool of soil C, N, and P. Indeed, it has been suggested that the amount of $\mathrm{N}$ and $\mathrm{P}$ contained within the soil microorganism biomass is comparable to the $\mathrm{N}$ and 
81 P content within the plant biomass in desert ecosystems (Coleman \& Whitman 2005). Moreover,

82 microbial communities can help accelerate the transformation of molecules containing $\mathrm{C}, \mathrm{N}$, and

83 P by producing soil extracellular enzymes (ecoenzymes) (Sinsabaugh \& Follstad Shah 2012;

84 Sinsabaugh et al. 2009) that lead to the fragmentation, depolymerization and mineralization of

85 organic matter (Singh et al. 2014). Microorganisms can only assimilate soluble organic

86 compounds of a molecular weight lower than $1 \mathrm{kDa}$ and must therefore break down, or

87 depolymerize, most of the organic matter molecules (where between 72 and $87 \%$ of the DOC in

88 grassland soils is larger than $1 \mathrm{kDa}$ ) in order to access the nutrients and energy contained within

89 the organic molecules (Cregger et al. 2012; Farrell et al. 2014; Jones et al. 2012). The

90 microorganisms produce hydrolytic or oxidative ecoenzymes that degrade organic matter,

91 producing assimilable dissolved organic nutrients that are rapidly immobilized within their

92 biomass (Conant et al. 2011; Sinsabaugh \& Follstad Shah 2012). Additionally, in desert

93 ecosystems, the natural distribution of different vegetation types can produce spatial

94 heterogeneity in the quantity and quality of organic matter (Austin et al. 2004; Housman et al.

95 2007). In these ecosystems, the depolymerization process will therefore require the production of

96 different ecoenzymes, since the organic matter under each vegetation type contains a particular

97 combination of structurally simple and complex molecules that promote differences in the soil

98 nutrient dynamics mediated by the microbial community (Conant et al. 2011). However, the

99 complete organic matter decomposition process requires a chain of enzymatic reactions where

100 each ecoenzyme acts on a different substrate and is produced by different microbial groups

101 (Ekschmitt et al. 2005). Additionally, the soil microbial communities can exhibit functional

102 redundancy in the ecoenzyme production (Allison \& Martiny 2008). 
103 Soil microorganisms have developed mechanisms of physiological acclimatization to cope with 104 precipitation variability (Schimel \& Schaeffer 2012). These mechanisms generate physiological costs for the microbial community that derive from the need for high investments of energy (C) and nutrients ( $\mathrm{N}$ and $\mathrm{P}$ ) in order to survive (Classen et al. 2015; Schimel et al. 2007; Schimel \& Schaeffer 2012). This high demand for energy (C) and nutrients ( $\mathrm{N}$ and $\mathrm{P}$ ) can be offset by reallocation of these resources, generating a trade-off in which the microbial community invests C, N and P in either growth or survival (Evans \& Wallenstein 2012; Schimel et al. 2007). Some consequences of such resource redirection are: 1) a limited production of ecoenzymes for nutrient acquisition (i.e. for SOM decomposition) (Burns et al. 2013; Henry 2013; Steinweg et al. 2013) and 2) reduced growth of the microbial community (i.e. decreased protein synthesis)

113 (Schimel et al. 2007). Resource reallocation increases the vulnerability of some microbial groups that produce a change in the structure and function of the soil microbial community also affecting the energy flow (C) and nutrient dynamics of $\mathrm{N}$ and $\mathrm{P}$ at the ecosystem level (Esch et al. 2016; Evans \& Wallenstein 2012; Thibault \& Brown 2008). This variability strongly affects microbial community development in resource-limited environments, because the adaptation rates of microbial species are constrained by the resource cost of physiological adjustment (Wallenstein \& Hall 2012). Wallenstein and Hall (2012) proposed that sites limited by nutrients are more vulnerable to annual rainfall variability, because the microbial community must invest energy in nutrient acquisition, and consequently reducing its capacity for adaptation required by

122 fluctuation in water availability. Sites with low resource availability could be therefore more 123 vulnerable to annual precipitation variability.

124 The Chihuahuan desert has been classified as one of the most biologically outstanding habitats 125 globally by the World Wildlife Fund (Archer \& Predick 2008). The Cuatro Ciénegas Basin 
126 (CCB), which is the study site of the present investigation, is part of the Chihuahuan desert and

127 is considered the most important wetland of Mexico for its high levels of endemism and

128 biodiversity (Souza et al. 2011). Moreover, the CCB has been listed as an ultra-oligotrophic site

129 due to low $\mathrm{P}$ concentrations in the water and soil, which can constitute a strong potential for P

130 limitation of microbial growth (Elser et al. 2005; Tapia-Torres et al. 2015a). A study in the CCB

131 desert reported that, in the same soil type with different vegetation cover (grassland and desert

132 scrub) differences in OM content promotes variation in DOC concentration, which represents the

133 main energy source for soil microorganisms (Tapia-Torres et al. 2015b). The higher DOC

134 concentration under grassland soil compared to desert scrub soil favored a higher microbial $\mathrm{N}$

135 immobilization and a higher $\mathrm{C}$ availability, therefore significantly reducing soil $\mathrm{N}$ losses (Tapia-

136 Torres et al. 2015b). Another study in the CCB that compared two sites with different soil

137 moisture content showed that the site with the highest moisture content and concentration of

138 DOC also exhibited higher $\mathrm{NH}_{4}{ }^{+}$, microbial $\mathrm{C}$ and $\mathrm{N}$ concentrations, and also presented higher

139 diversity, richness and evenness of soil bacterial community compared to the dry site (López-

140 Lozano et al. 2012). Both studies suggest that differences in DOC concentration (energy

141 availability) and microbial community composition promoted different nutrient dynamics. In the

142 sites with organic matter providing lower DOC concentrations, the microbial communities may

143 be co-limited by energy and nutrients and yet they must invest more energy in order to obtain the

144 most limiting nutrients. An indicator that helps us understand how resources are reallocated by

145 the microbial community to cope with the nutrient limitation is the combination of: 1) the

146 stoichiometry ratios of C:N:P in the soil and microbial biomass (Cleveland \& Liptzin 2007) and

147 2) the Threshold Elemental Ratio (TER) (Sinsabaugh \& Follstad Shah 2012; Tapia-Torres et al.

148 2015a), which defines the element ratio at which growth is affected by nutrient limitation 
149 (represented by $\mathrm{N}$ and $\mathrm{P}$, at high $\mathrm{C}: \mathrm{N}$ or $\mathrm{C}: \mathrm{P}$ ) and by energy limitation (represented by $\mathrm{C}$, at low

150 C:N or C:P) (Frost et al. 2006; Sterner \& Elser 2002). The combination of stoichiometry ratios

151 and TER indicate how resources are reallocated towards enzyme activity depending on the

152 availability of energy (C) and nutrients (N and $\mathrm{P})$ in the soil. This microbial co-limitation

153 between energy and nutrient acquisition was also found in CCB by comparing the TER $\mathrm{C:N}_{\mathrm{N}}$ and

154 TER $_{\mathrm{C}: \mathrm{P}}$ from two sites with the same vegetation cover (grassland), but different soil moisture and 155 DOC availability values (Tapia-Torres et al. 2015a). The microbial communities were co-limited 156 by $\mathrm{C}$ and $\mathrm{N}$ in the site with higher water and $\mathrm{C}$ availability (Churince) and were co-limited by $\mathrm{C}$ 157 and $\mathrm{P}$ in the site with lower water and $\mathrm{C}$ availability (Pozas Azules). In addition, these authors 158 argue that this limitation favors an elevated allocation of $\mathrm{N}$-acquisition enzymes relative to 159 energy/C enzymes in Churince, while for Pozas Azules, an elevated investment in ecoenzymes 160 of $\mathrm{P}$ acquisition is found (Tapia-Torres et al. 2015a). These results support the notion that soil 161 microbial communities can adjust their metabolism by allocating more resources (i.e. energy and 162 production of ecoenzymes) to the accumulation of scarcer nutrients, and fewer resources to the 163 acquisition of abundant nutrients. The ratios of $\mathrm{C}: \mathrm{N}: \mathrm{P}$ in microbial biomass are therefore

constrained relative to nutrient (Cleveland \& Liptzin 2007) and energy availability. These studies suggest that both vegetation and soil moisture content may determine differences in: 1) soil nutrient dynamics, 2) the diversity of the soil microbial community and 3) the C:N:P ratios of the microbial biomass in this ecosystem.

To date, the physiological adjustments made by the soil microbial communities under different soil resource availability in order to obtain energy and nutrients in desert ecosystems with high precipitation variability remain unclear. To elucidate this dynamic, the present study examined the effects of rainfall variation on the physiological adjustments made in order to obtain energy 
172 and nutrients by the soil microbial community from two vegetation-soil systems with different

173 soil organic matter inputs in an oligotrophic desert ecosystem. Our hypothesis is that, in a site

174 with high soil resources availability, the soil microbial communities invest less energy in the

175 acquisition of nutrients (i.e. ecoenzymatic production), favoring nutrient accumulations within

176 the biomass (i.e. immobilization). Our predictions are: 1) in a site that presents low soil nutrient

177 availability (rosetophylous scrub - RS), the soil microbial community will invest more energy in

178 the production of ecoenzymes in order to depolymerize and mineralize, thus favoring nutrient

179 availability; while in a site with high soil nutrient availability (grassland - G), the soil microbial

180 community will invest more energy in biomass growth; and 2) in the site with greater soil

181 resources availability $(\mathrm{G})$, the microbial community will be less vulnerable to changes in

182 precipitation. To test the hypothesis, we collected soil samples in the CCB from sites under two

183 vegetation covers (RS and G) that differ in terms of the quantity and quality of the organic matter

184 present. Collections were conducted during years: 2011(February), 2012, 2013 and 2014

185 (September), over which a noticeable variation in annual precipitation took place. The

ecoenzyme activity involved in the decomposition of organic matter, as well as the concentration

187 of dissolved, available and microbial biomass nutrient, were determined and compared between

sites and years. With the ecoenzymatic and biogeochemistry data we calculated the $\mathrm{TER}_{\mathrm{C} \text { : nutrient, }}$

189 SEA, the nutrient ratios and performed regressions between the precipitation and the concentrations and ratios of $\mathrm{C}, \mathrm{N}$ and $\mathrm{P}$ in microbial biomass.

192 Material and methods

193 2.1.Study site 
194 The study was carried out in the Cuatro Ciénegas Basin (CCB; $26^{\circ} 45^{\prime}-27^{\circ} 00^{\prime} \mathrm{N}$ and $101^{\circ} 48^{\prime}-$

$195102^{\circ} 17^{\prime}$ W) in central northern Mexico, within the Chihuahuan Desert. The CCB has an area of

$196150,000 \mathrm{~km}^{2}$, with an elevation of 740 m.a.s.l. The climate is arid with an average annual

197 temperature of $21^{\circ} \mathrm{C}$ and $252 \mathrm{~mm}$ of annual rainfall, which is concentrated during the summer

198 months (http://smn.cna.gob.mx/). However in the last 30 years the annual precipitation showed a

199 high variability among years. In this study the annual precipitation was estimated as the amount

200 of rain accumulated 9-months before the sampling month. The precipitation data were obtained

201 from meteorological station 5044 “Cuatro Cienegas” located at 2659'0' $\mathrm{N}$ and $101^{\circ} 04^{\prime} 0$ ' ' W

202 (http://smn.cna.gob.mx/). Annual precipitation and the average temperature of the sampling

203 months varied strongly during the four studied years: The year 2011 was the wettest year (348

$204 \mathrm{~mm}$ and $\left.25^{\circ} \mathrm{C}\right), 2012$ was particularly dry and hot $\left(89 \mathrm{~mm}\right.$ and $\left.28^{\circ} \mathrm{C}\right)$ and was followed by two

205 wet years (217 mm and $230 \mathrm{~mm}$ for 2013 and 2014, respectively) with lower temperatures (24.9

206 and $24.8^{\circ} \mathrm{C}$ for 2013 and 2014 , respectively).

207 Jurassic-era gypsum is the dominant parent material on the western side of the basin (McKee et

208 al. 1990). According to the WRB classification (2007), the predominant soil on the western side

209 of the basin is Gypsisol. The main vegetation types are: 1) grassland (G), dominated by

210 Sporobolus airoides (Torr.) Torr. and Allenrolfea occidentalis (S. Watson) Kuntze; 2) microphyll

211 scrub, dominated by Jatropha dioica Cerv., Larrea tridentate (DC) Cov. and Fouqueria sp

212 Kunth (Perroni et al. 2014a); and 3) rosetophylous scrub (RS) dominated by Dhasylirium

213 cedrosanum Trel., and Yucca treculeana Carriére (González 2012).

\section{1.2. Sampling}

215 Mean air temperature for the sampling month (September) and annual rainfall data in each

216 studied year were obtained from the meteorological station "Rancho Pozas Azules" INIFAP. Soil 
217 collection was carried out in Churince on the west side of the CCB, where Gypsisol is the

218 predominant soil type (Perroni et al. 2014b). The samples were taken from two vegetation cover

219 types, rosetophylous scrub (RS) and grassland (G), during February (2011) and September (rainy

220 of 2012, 2013 and 2014). For each vegetation cover, we sampled seven sites located at a distance

221 of $140 \mathrm{~m}$ apart, along a one km north-to-south transect. At each sampling site, a 4 x $4 \mathrm{~m}$ plot was

222 demarcated and five soil samples were taken from the first $15 \mathrm{~cm}$ of soil depth within the plot,

223 and mixed to produce one compound sample per site. A total of seven composite samples were

224 therefore obtained from each vegetation cover in each sampling year. The soil samples were

225 stored in black plastic bags at $4^{\circ} \mathrm{C}$ until subsequent laboratory analysis.

226

227 1.3. Moisture and $\mathrm{pH}$

228 Soil $\mathrm{pH}$ was measured in deionized water (soil/solution, 1:2 w:v) with a digital $\mathrm{pH}$ meter

229 (Corning $\left.{ }^{\mathrm{TM}}\right)$. A subsample of $100 \mathrm{~g}$ was oven-dried at $75^{\circ} \mathrm{C}$ to constant weight for soil moisture

230 determination using the gravimetric method.

231

232 1.4. Biogeochemical analyses

233 2.4.1. Nutrient Analysis

234 All Carbon (C) forms analyzed were determined with a Total Carbon Analyzer (UIC Mod.

235 CM5012; Chicago, USA), while nitrogen (N) and phosphorus (P) concentrations were

236 determined by colorimetric analyses, using a Bran Luebbe Auto Analyzer III (Norderstedt,

237 Germany). Microbial P and enzymatic activity were determined by colorimetric analyses using a 238 spectrophotometer Evolution 201 (Thermo Scientific Inc.). 


\subsubsection{Total nutrients}

241 Prior to analysis of total nutrient forms, soil samples were dried and milled with a pestle and

242 agate mortar. Total C (TC) and inorganic C (IC) were determined by combustion and

243 coulometric detection (Huffman 1977). Organic total C (OTC) was calculated as the difference

244 between TC and IC. For total N (TN) and total P (TP) determination, the samples were digested

245 in a mixture of concentrated $\mathrm{H}_{2} \mathrm{SO}_{4}, \mathrm{H}_{2} \mathrm{O}_{2}(30 \%)$ and $\mathrm{K}_{2} \mathrm{SO}_{4}$ plus $\mathrm{CuSO}_{4}$, the latter acting as a

246 catalyst at $360^{\circ} \mathrm{C}$. Nitrogen was determined by the macro Kjeldahl method (Bremmer 1996),

247 while $\mathrm{P}$ was determined by the molybdate colorimetric method, following ascorbic acid

248 reduction (Murphy \& Riley 1962).

249

\section{2.4.3. Dissolved and available nutrients and those within the microbial biomass}

251 The dissolved, available and microbial nutrient forms were extracted from fresh field soil

252 samples. Dissolved nutrients were extracted from $20 \mathrm{~g}$ of soil with deionized water after shaking

253 for $45 \mathrm{~min}$ and then filtering through a Whatman No. 42 and a $0.45 \mu \mathrm{m}$ nitrocellulose membrane

254 (Jones \& Willett 2006). The filtrate was used to determine the total dissolved C (TDC), as

255 measured with an Auto Analyzer of carbon (TOC CM 5012) module for liquids (UIC-

256 COULOMETRICS). Inorganic dissolved C (IDC) was determined in an acidification module

257 CM5130. One aliquot of the filtrate was used to determine ammonium $\left(\mathrm{DNH}_{4}{ }^{+}\right)$and dissolved

258 inorganic P (DIP) in a deionized water extract. Total dissolved $\mathrm{N}$ and P (TDN and TDP,

259 respectively) were digested in a mixture of concentrated $\mathrm{H}_{2} \mathrm{SO}_{4}, \mathrm{H}_{2} \mathrm{O}_{2}(30 \%)$ at $250{ }^{\circ} \mathrm{C}$. Nitrogen

260 was determined by the macro Kjeldahl method (Bremmer 1996), while P was determined by the

261 molybdate colorimetric method, following ascorbic acid reduction (Murphy \& Riley 1962). 
262 Dissolved organic C, N and P (DOC, DON and DOP respectively) values were calculated as the

263 difference between the total dissolved forms and the inorganic dissolved forms.

264 Available inorganic nitrogen forms $\left(\mathrm{NH}_{4}{ }^{+}\right.$and $\left.\mathrm{NO}_{3}{ }^{-}\right)$were extracted from $10 \mathrm{~g}$ of soil with $2 \mathrm{M}$

$265 \mathrm{KCl}$, followed by filtration through a Whatman No. 1 paper filter, and determined

266 colorimetrically by the phenol-hypochlorite method (Technicon 1977). Available inorganic

267 phosphorous (Pi) was extracted with $0.5 \mathrm{M} \mathrm{NaHCO}_{3}, \mathrm{pH} 8.5$ (Tiessen \& Moir 2008) and

268 determined colorimetrically using the molybdate-ascorbic acid method (Murphy \& Riley 1962).

269 Carbon ( $\mathrm{Cmic}$ ) and $\mathrm{N}$ (Nmic) concentrations within the microbial biomass were determined from

$27020 \mathrm{~g}$ of soil by the chloroform fumigation extraction method (Vance et al. 1987). Fumigated and

271 non-fumigated samples were incubated for $24 \mathrm{~h}$ at $25^{\circ} \mathrm{C}$ and constant relative humidity. Cmic

272 and Nmic were extracted from fumigated and non-fumigated samples with $0.5 \mathrm{MK}_{2} \mathrm{SO}_{4}$, filtered

273 through a $0.45 \mu \mathrm{m}$ nitrocellulose membrane (Brookes et al. 1984). Carbon concentration was

274 measured from each extract, as the total (TC) and inorganic (IC) carbon contents, using the

275 method described before. The difference between TC and IC was used for Cmic calculation. To

276 determine the Nmic concentration one aliquot of the filtrate extracted was acid digested and

277 determined as TN by Macro-Kjeldahl method (Brookes et al. 1984). Phosphorus within

278 microbial biomass (Pmic) was extracted from $5 \mathrm{~g}$ of soil by the chloroform fumigation extraction

279 and incubation method (Vance et al. 1987). Pmic was extracted using $\mathrm{NaCO}_{3} 0.5 \mathrm{M}, \mathrm{pH} 8.5$ and

280 digested in a mixture of $\mathrm{H}_{2} \mathrm{SO}_{4} 11 \mathrm{~N}$ and $\left(\mathrm{NH}_{4}\right)_{2} \mathrm{~S}_{2} \mathrm{O}_{8}$ at $50 \%$, with the latter acting as a catalyst at

$281120{ }^{\circ} \mathrm{C}$ (Lajtha et al. 1999). Pmic was determined colorimetrically by the molybdate-ascorbic

282 acid method (Murphy \& Riley 1962). The values of Cmic, Nmic and Pmic were calculated as

283 the difference between fumigated and non-fumigated samples using correction factors of $\mathrm{K}_{\mathrm{EC}}$

2840.45 (Joergensen 1996), $K_{\mathrm{EN}} 0.54$ (Joergensen \& Mueller 1996) and $\mathrm{K}_{\mathrm{P}} 0.4$ (Lajtha et al. 1999) 
285 for Cmic, Nmic and Pmic, respectively. Finally, the values of Cmic, Nmic and Pmic were 286 corrected to a dry soil basis.

287

288

289

290

291

292

293

294

295

296

297

298

299

300

301

302

303

304

305

306

\subsection{Molecular analysis}

Bacterial composition analysis was performed on the samples from the wettest year (2011). We extracted DNA from each soil sample using the methodology described in López-Lozano (2013) and sent it to J. Craig Venter Institute (JCVI) in order to construct a 16S library using 454 ROCHE tag, 50,000 reads per site of $500 \mathrm{bp}$ and primers 341F-926R. Sequences were trimmed and chimeras eliminated using JCVI protocols. Taxa were assigned using Blast via JCVI pipeline, these methods are detailed by Tanenbaum et al. (2010).

\subsection{Ecoenzyme Activity Analyses}

The activities of six ecoenzymes (extracellular enzymes) involved in the cleavage of organic molecules with $\mathrm{C}, \mathrm{N}$ and $\mathrm{P}$ were measured: $\beta$-1, 4-glucosidase (BG), cellobiohydrolase $(\mathrm{CBH})$, $\beta-1,4-\mathrm{N}$-acetylglucosaminidase (NAG), polyphenol oxidase (PPO), phosphomonoesterase (PME) and phosphodiesterase (PDE), using assay techniques reported by Tabatabai \& Bremner (1969), Eivazi \& Tabatabai (1977), Eivazi \& Tabatabai (1988),Verchot \& Borelli (2005) and Johannes \& Majcherczyk (2000).

For all ecoenzymes, we used $2 \mathrm{~g}$ of fresh soil and $30 \mathrm{ml}$ of modified universal buffer (MUB) at pH 9 for ecoenzyme extraction. Three replicates and two control samples (soil extract with no substrate, and pure MUB with substrate) were included per assay. All ecoenzyme assays were incubated at $40^{\circ} \mathrm{C}$ : the $\mathrm{BG}$ and $\mathrm{CBH}$ for $2 \mathrm{~h}, \mathrm{NAG}$ for $3 \mathrm{~h}, \mathrm{PPO}$ for $2.5 \mathrm{~h}, \mathrm{PME}$ and PDE $1.25 \mathrm{~h}$. 
307 Following the incubation period, the tubes were centrifuged at 10,000 rpm for 2 minutes and

$308750 \mu 1$ of supernatant was recovered.

309 For all ecoenzymes with substrates containing p-nitrophenol (pNP), we diluted the supernatant in

$3102 \mathrm{ml}$ of deionized water with $75 \mu \mathrm{l}$ of $\mathrm{NaOH}$ and measured the absorbance of pNP liberated at

$311410 \mathrm{~nm}$ on an Evolution 201 spectrophotometer (Thermo Scientific Inc.). For the PPO, we used

312 2,2'-Azinobis [3-ethylbenzothiazoline-6-sulfonic acid]-diammonium salt (ABTS) as a substrate.

313 The resulting supernatant was measured directly at $410 \mathrm{~nm}$. Ecoenzyme activities were

314 expressed as nanomoles of pNP per gram of dry soil per hour (nmol pNP $\left[\mathrm{g} \mathrm{SDE}^{-1} \mathrm{~h}^{-1}\right)$ for

315 substrates containing p-nitrophenol (pNP) and $\mathrm{O}_{2}$ formed per gram of dry soil per hour (nmolO

$316\left[\mathrm{~g} \mathrm{SDE}^{-1} \mathrm{~h}^{-1}\right.$ ) for the PPO, respectively. Specific enzymatic activity was calculated using

317 equations (1) to (3) (Chavez-Vergara et al. 2014; Waldrop et al. 2000):

$318 S E A \mu \mathrm{mol} /\left(m g C_{m i c} h\right)=A /\left(C_{\text {mic }} \times 0.001\right)$

$319 S E A \mu \mathrm{mol} /\left(\mathrm{mgN}_{\text {mic }} h\right)=B /\left(N_{\text {mic }} \times 0.001\right)$

$S E A \mu \mathrm{mol} /\left(m g P_{\text {mic }} h\right)=C /\left(P_{\text {mic }} x 0.001\right)$

321

322

323

324

325

326

327

328

329

Where $\mathrm{A}$ is the enzymatic activity of $\mathrm{BG}$ or $\mathrm{CBH}$ or PPO, $\mathrm{B}$ is the enzymatic activity of NAG and $\mathrm{C}$ is the enzymatic activity of PME or PDE.

\subsection{Data analysis}

\subsubsection{Biogeochemistry and ecoenzymatic analysis}

Soil biogeochemistry and ecoenzymatic data were subjected to a repeated measures analysis of variance (RMANOVA) (Von Ende 2001). Vegetation cover types (RS and G) were considered as a between-subject factor and year (2012, 2013 and 2014), and their interaction, were considered as within-subject factors. When RMANOVA indicated significant factor effects, 
mean comparisons were performed with Tukey's multiple comparisons test (Von Ende 2001).

331 Ecoenzyme activities were normalized to units per $\mu \mathrm{g}$ of available organic carbon (OC) using the

332 DOC data corresponding to each sample (Tapia-Torres et al. 2015a). Data were $\log _{\mathrm{e}}$-transformed

333 prior to regression analysis in order to conform to the conventions of stoichiometric analyses and

334 to normalize variance (Sinsabaugh \& Follstad Shah 2012; Sterner \& Elser 2002). After that,

335 relationships between ecoenzyme activities were calculated with a type II regression, using

336 SMATR (SMATR 2007).

337 To detect the relationship between precipitation and nutrients immobilized by microbial biomass, 338 we applied two simple regression analyses using the annual accumulated precipitation prior to

339 the sampling date with: 1) nutrient concentration within the microbial biomass (Cmic, Nmic and 340 Pmic) and 2) the microbial biomass nutrient ratios (Cmic:Nmic, Cmic:Pmic and Nmic:Pmic).

341 The data used in the regression analyses corresponded to the years 2011, 2012, 2013 and 2014.

342 2.7.2. Stoichiometric analyses and threshold elemental ratio

343 We calculated the degree of soil community-level microbial C:N and C:P homeostasis by

344 calculating the slope of $\log _{e} C: N_{R}$ (resources) versus $\log _{e} C: N_{B}$ (microbial biomass) or the slope

345 of $\log _{e} C: P_{R}$ versus $\log _{e} C: P_{B}$ scatterplot (Sterner \& Elser 2002). Moreover, we followed

346 Sinsabaugh et al. (2009) in order to calculate the TER for C:N and C:P to relate the measured

347 ecoenzyme activity with Ecological Stoichiometry Theory (EST) and the Metabolic Theory of

348 Ecology (MTE), using equations (5) and (6):

$349 \quad \mathrm{TER}_{\mathrm{C}: \mathrm{N}}=\left((\mathrm{BG} / \mathrm{NAG}) \mathrm{B}_{\mathrm{C}: \mathrm{N}}\right) / n_{0}(5)$

$350 \quad \mathrm{TER}_{\mathrm{C}: \mathrm{P}}=\left((\mathrm{BG} / \mathrm{PME}) \mathrm{B}_{\mathrm{C}: \mathrm{P}}\right) / p_{0}(6)$

351 Where TERC:N and TERC:P are the threshold ratios (dimensionless), BG/NAG is the

352 ecoenzymatic activity ratio for $\beta$-1,4-glucosidase and $\beta$-1,4-N-acetylglucosaminidase, BG/PME 
353 is the ecoenzymatic ratio for $\beta$-1,4-glucosidase and phosphomonoesterase, $\mathrm{BC}: \mathrm{N}$ and $\mathrm{BC}: \mathrm{P}$ are

354 the $\mathrm{C}: \mathrm{N}$ or $\mathrm{C}: \mathrm{P}$ ratios of the microbial biomass (respectively) and $n 0$ and $p 0$ are the

355 dimensionless normalization constants for $\mathrm{N}$ and $\mathrm{P}$, respectively. These normalization constants

$356 p_{0}$ and $n_{0}$ are the intercepts in the SMA regressions for $\log _{\mathrm{e}}(\mathrm{BG}) v s . \log _{\mathrm{e}}(\mathrm{NAG})$ and $\log _{\mathrm{e}}(\mathrm{BG})$

357 vs. $\log _{\mathrm{e}}(\mathrm{PME})$ respectively (Tapia-Torres et al. 2015a). For a more detailed analysis of the

358 derivation of the equations, see Sinsabaugh et al. (2009).

2. Results

361

2.1. Soil moisture, and $p H$

362 Regardless of vegetation cover, soil moisture was higher in 2013 and 2014 than in 2012; while 363 the G soil had higher soil moisture than the RS soil, regardless of year (Table 1 and 2 ). In the 364 driest year (2012), soil pH was higher than in the wetter years (2013 and 2014), with an 365 exception in the $\mathrm{G}$ soil in 2014 (Table 1 and 2). Soil $\mathrm{pH}$ correlated with annual precipitation in 366 both sites $\left(\mathrm{R}^{2}=-0.85\right.$ and $\mathrm{R}^{2}=-0.61$ for $\mathrm{RS}$ and $\mathrm{G}$, respectively), as well as soil moisture 367 correlated with annual precipitation $\left(\mathrm{R}^{2}=0.76\right.$ and $\mathrm{R}^{2}=0.88$ for $\mathrm{RS}$ and $\mathrm{G}$, respectively). 368

\subsection{Dissolved organic nutrients and available nutrients}

370 For the two vegetation covers, the lowest values of DOC, DON and DOP were found in 2012

371 (Table 1). In this year, the RS and the G soils had similar DOC and DOP concentrations, while

372 the G soil had a higher DON concentration than the scrub soil; moreover, the G soil had higher

373 dissolved organic nutrient concentrations than in the RS soil in both 2013 and 2014 (Table 1 and

374 2). Consequently, the DOC:DON ratio was lower in 2012 than in the other two years (2013 and 
375 2014) and the RS soil had lower values than the G soils (3.5 and 4.9, respectively); the RS soil

376 also had lower DOC:DOP ratios than the G soil (9 and 16, respectively).

377 The year trends of available $\mathrm{NH}_{4}{ }^{+}$concentration differed between the two vegetation cover types.

378 Available $\mathrm{NH}_{4}{ }^{+}$concentration was similar over the three years in the RS soil, while G soil

379 samples from 2012 and 2013 had the lowest and the highest $\mathrm{NH}_{4}{ }^{+}$concentrations, respectively

380 (Table 1 and 2). However, the G soil had higher values than the RS soil in the three studied

381 years. In contrast, the $\mathrm{NO}_{3}{ }^{-}$concentration was higher in the samples collected in 2012 than those

382 of the other two years, while the RS soil had higher $\mathrm{NO}_{3}^{-}$concentration than the G soil only in

383 the 2012 samples (Table 1 and 2). The 2012 samples had lower available $\mathrm{P}$ concentration than in

384 those collected in the other two years, and the $\mathrm{G}$ samples had $40 \%$ higher available $\mathrm{P}$

385 concentration than the RS samples, regardless of the sampling year $\left(4.1\right.$ and $2.9 \mu \mathrm{g} \mathrm{P} \mathrm{g}^{-1}$,

386 respectively).

387

388

\subsection{Microbial nutrients and ecoenzymatic activities}

389

390

391

392

393

394

395

396

397

The highest and the lowest values of Cmic and Nmic were found in 2014 and 2012, respectively, and Cmic values of the G soil samples were 39\% higher than in the RS soil samples, regardless of sampling year (254 and $184 \mu \mathrm{g} \mathrm{C} \mathrm{g}{ }^{-1}$, respectively). This was also the case with the Nmic and Pmic concentrations, with an exception in the 2012 samples (Table 3 and 4). In contrast, Pmic concentrations presented no differences among years within the RS samples, while the 2012 samples had lower Pmic values than was the case in the other two years, within the G samples (Table 3 and 4). The 2014 samples had lower Cmic:Nmic than the other two years regardless of vegetation cover type (2012 and 2013), while the lowest and the highest Cmic:Pmic and Nmic:Pmic ratios were found in 2012 and 2014, respectively (Table 3 and 4). The RS soil 
398 samples had higher Cmic:Pmic and Nmic:Pmic ratios than in the G soil samples, with an

399 exception in the 2012 samples (Table 3 and 4).

400 Significant positive correlations were observed between precipitation and immobilized nutrients 401 within the microbial biomass (Cmic, Nmic, Pmic), in both soils. Moreover, significant positive 402 correlations were detected between precipitation and the Cmic:Nmic and Cmic:Pmic ratios in the 403 RS soil and the Cmic:Pmic and Nmic:Pmic ratios in the G soil. The slopes of the regression with 404 Cmic and Nmic were higher in the G soil and lower in the RS soil (Fig.1, Fig. 2 and Table S1). 405 The specificenzymatic activity of BG under both vegetation cover types was lower in the wet 406 (2014) than in the dry year (2012; Figure 3a, Table 4), while that of CBH in the dry year was 407 lower than in both wet years (2013 and 2014), in both vegetation covers (Fig. 3b). The specific 408 enzymatic activity of the PPO in the scrub soil did not differ among years, while the dry year 409 (2012) had lower values than the wet years (2013 and 2014) in the G soil (Fig. 3c and Table 4).

410 Furthermore, the G soil had higher specific PPO enzimatic activity than the RS soil in the wet 411 year (2014). In contrast, the wet year (2014) had the lowest NAG specific enzymatic activity 412 under both vegetation cover types, and the RS soil had lower values only in the dry year (2012; 413 Fig. 3d). The specific enzymatic activity of PME and PDE was similar, and the lowest values of 414 specific enzymatic activity were in the driest year (2012). In the two wet years, the RS soil 415 presented higher specific activities than the $\mathrm{G}$ soil (Fig $3 \mathrm{e}$ and $3 \mathrm{f}$ ).

\subsection{Soil bacterial composition}

418 Even at 97\% similarity, a very high diversity was found, encompassing all the known phyla of 419 bacteria but a very low diversity and abundance of Archaea. A total of 46,898 sequences were 420 obtained for the RS soil and 9,979 for the G soil, comprising 24 phyla. We observed a high 
421 number of unclassified bacteria; $26 \%$ for the RS soil and 20\% for the G soil (Fig. 4). In the two

422 vegetation cover types, the Proteobacteria was the most abundant bacterial phylum, accounting

423 for $20 \%$ in the RS soil and $30 \%$ in the G soil. Similarly, Actinobacteria was the second most

424 dominant phylum in the RS soil and in the G soil, with an abundance of $14 \%$ in both soils.

425 Interestingly, the Cyanobacteria was the third most dominant phylum, with $13 \%$ of abundance

426 both soils, suggesting the importance of the desert crust in both sites. Other important phyla

427 observed were: Chloroflexi (10\%), Bacteroidetes (5\%), Plantomycetes (4\%), Firmicutes (4\%),

428 Nitrospira ( $1 \%$ in the RS and $0.5 \%$ in the G soils) and Acidobacteria ( $6 \%$ in RS and $0.8 \%$ in G;

429 Fig. 4).

430

4313.5 Ecoenzymatic stoichiometry, homeostasis and threshold elemental ratios

432 In all of the model II regressions analyzed, there were no differences found in slopes between

433 soils of the two vegetation cover types within sampling years (Figures S1 and S2). To test the

434 strength of stoichiometric homeostasis, we analyzed for associations between microbial biomass

435 elemental ratios and those in the soil resources (Tapia-Torres et al. 2015a). In both soil

436 vegetation cover types, the relationships between $\log C: N_{R}$ and $\log C: N_{B}$, and between $\log C: P_{R}$

437 and $\log \mathrm{C}: \mathrm{P}_{\mathrm{B}}$ did not differ from zero $(\mathrm{p}>0.05)$, regardless of year (Figures $\mathrm{S} 1$ and $\left.\mathrm{S} 2\right)$;

438 indicating strong community-level elemental homeostasis in the soil of both sites.

439 Moreover, we used the parameters generated from the type II regressions using enzymatic data

440 and microbial C:N:P stoichiometric values to estimate $\mathrm{TER}_{\mathrm{C}: \mathrm{N}}$ and $\mathrm{TER}_{\mathrm{C}: \mathrm{P}}$ values. The lowest

441 TER $_{\mathrm{C}: \mathrm{N}}$ values were observed in 2014 (wet year), but no differences were observed between 2012

442 and 2013, or even between vegetation cover types (RS and G) among study years (Fig. 5). The

443 opposite was found for TER $\mathrm{T}_{\mathrm{C} P \mathrm{P}}$, where we obtained the lowest value in the dry year (2012), but 
444 only in the RS soil. For the dry year (2012), no differences were observed between vegetation

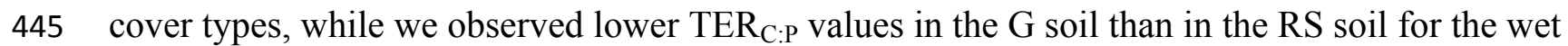
446 years (2013 and 2014; Fig. 5).

447

448

\section{Discussion}

\subsection{Reallocation of resources by the soil microbial community}

450 Our first prediction, that the soil microbial community invests more energy in the production of ecoenzymes to acquire nutrients in sites of low resource availability, such as the RS soil, was

452 confirmed. We observed that the RS soil showed a lower concentration of available P than the G soil in the three years studied and, consequently, the RS soil microbial community invested more energy in the acquisition of $\mathrm{P}$ (increased enzymatic activity of phosphomonoesterase and phosphodiesterase) than the G soil microbial community only during the two wet years. In contrast, the G soil had higher Cmic, Nmic and Pmic concentrations and lower enzymatic activity of phosphomonoesterase and phosphodiesterase than the RS soil during both wet years, which also supports our prediction (Fig 1 and Table 3 ). These results suggest that the microbial community in the RS soil, with lower resource availability, must reduce growth as a result of: 1) the physiological cost associated with a low reallocation to P-rich ribosomal RNA, as suggested by the growth rate hypothesis (GRH) (Sinsabaugh \& Follstad Shah 2012; Sterner \& Elser 2002; Zechmeister-Boltenstern et al. 2015) and 2) the required investment of energy towards the acquisition of P in order to produce ecoenzymes (Evans \& Wallenstein 2012; Schimel et al. 2007; Wallenstein \& Hall 2012). The microbial C:N:P ratio was greater in the RS soil (127:19:1) than in the G soil (63:10:1), suggesting that the microbial community in the former site is more Pconstrained (Cleveland \& Liptzin 2007). The studied soils are characterized by low P availability 
467 and a high capacity for P occlusion within inorganic molecules, mainly by Ca-bound (Perroni et

468 al. 2014b). Therefore, the main source of available $\mathrm{P}$ is mineralization of organic $\mathrm{P}$ mediated by

469 phosphatase activity (Waring et al. 2014). Among organic P molecules, phosphodiester forms are

470 the preferred substrate in P-limited ecosystems (Karl 2014; Tapia-Torres et al. 2016), although

471 phosphomonoester forms may also be an important source of available $\mathrm{P}$ in most soils (Turner et

472 al. 2003). In our study sites, phosphodiesterase activity was almost ten times higher than that of

473 phosphomonoesterase, mainly in the scrub soil, suggesting mineralization of phosphodiesters as

474 the main source of soil available P. Several bacteria isolates from CCB soils prefer to grow in

475 DNA as a P source, associated with phosphodiesterase activity (Tapia-Torres et al. 2016). We

476 suggest that the main P source in sites with low nutrient availability, such as the RS soil, is

477 recycling of the organic molecules that are the product of cellular lysis.

478 However, the $\mathrm{G}$ soil had higher enzymatic activity of polyphenol oxidase in the wet year 2014

479 than was the case in the RS soil. This result is consistent with other studies (Sinsabaugh 2010;

480 Sinsabaugh \& Follstad Shah 2011), which have reported that polyphenol oxidase activity does

481 not present the same behavior as the $\beta$-1, 4-glucosidase and other hydrolases that degrade labile

482 C. Microbial community size begins to be limited by the availability of labile C, which produces

483 a change in the microbial community composition towards microbial guilds with lower growth

484 rates (low concentration of $\mathrm{Cmic}$ ), but with the capacity to produce polyphenol oxidase to break

485 down structurally complex molecules and obtain C (Moorhead \& Sinsabaugh 2006). This

486 situation is comparable to the conditions of the G soil in the wet year 2014, where the microbial

487 community was required to cleave lignin in order to maintain its growth rate.

488 Furthermore, the differences in soil nutrient dynamics between both sites can be strongly

489 affected by soil microbial composition. While analyses of soil bacterial composition were only 
490 determined for 2011, this year presented the highest soil water availability and also showed

491 higher concentrations of Cmic, Nmic, and Pmic than in the other studied years. Several studies

492 (Nemergut et al. 2010; Philippot et al. 2009) have reported that heterotrophic decomposition

493 depends on the relative abundance of specific taxa because different species process organic

494 matter at different rates, even under similar soil conditions. The G soil had a higher proportion of

495 Proteobacterias, Actinobacterias and Bacteroidetes than the RS soil, and some species of these

496 taxa have the capacity to produce $\beta$-glucosidase (BG) (Moreno et al. 2013), cellobiohydrolase

497 (CBH), poliphenoloxidase (PPO) (T K Kirk \& Farrell 1987), glucanases and glycosidases (Xie et

498 al. 2007), which act to cleave C molecules.

499 In contrast, the scrub soil had higher proportion of Acidobaterias and Firmicutes, including

500 species with the capacity for producing enzymes for P mineralization (Koch et al. 2008; Tan et

501 al. 2013). Moreover, the acidobacterias of the RS soil could contribute to the release of

502 unavailable $\mathrm{P}$ through organic acid release (Tan et al. 2013) and, together with Firmicutes, can

503 mineralize P via the production of phosphatases, as has been observed in isolates of

504 acidobacterias from substrates with low C concentrations (Koch et al. 2008; Tan et al. 2013).

505 Chloroflexi was present in a higher proportion in the RS than in the G soil, but both soils had a

506 similar proportion of Cyanobacteria suggesting that the amount of microbial desert crust is

507 similar in both sites. Both phyla are facultative autotrophic bacteria (Smith 1983) and therefore

508 have the capacity to fix atmospheric $\mathrm{C}$ and to produce coenzymes for depolymerization and

509 mineralization of C (Berg et al. 2010; Mitsui et al. 1986; Smith 1983). The Cyanobacteria also

510 have the capacity to fix atmospheric N. Fixation in the microbial biomass of C and N by these

511 taxa could represent an important input of both nutrients to the soil (Mitsui et al. 1986; Smith

512 1983). Wallenstein \& Hall (2012) proposed that sites limited by nutrients are more vulnerable to 
513 rainfall variability, because the microbial community must invest energy in nutrient acquisition,

514 thus reducing its capacity for adaptation required by fluctuation in water availability. We

515 proposed that sites with low resources availability, such as the RS soil, could be thus more

516 vulnerable to annual precipitation variability.

517

518 3.2. Resilience in the face of precipitation changes

519 Our second prediction, that the microbial community will be more vulnerable to variability in

520 precipitation in the site with lower soil resources (RS), was not confirmed because the soil

521 community was resilient to soil $\mathrm{P}$ coinstrains by ecoenzyme upregulation during times of

522 adequate moisture. In both vegetation cover types, nutrient availability increased with increased

523 precipitation. The correlation between precipitation and the Cmic, Nmic and Pmic, indicate that a

524 higher amount of rainfall favored the microbial immobilization of these nutrients under both

525 vegetation cover types. Nevertheless, compared to the RS soil, the G soil showed steeper slopes

526 in regressions between the precipitation and the concentrations of Nmic and ratios of Cmic:Pmic

527 and Nmic:Pmic (Table S1), suggesting that the microbial community of the grassland soil has the

528 ability to immobilize more $\mathrm{N}$ within its microbial biomass and more rapidly than the microbial

529 community of the RS soil. Positive correlations between Cmic and rainfall have been reported

530 for an oak forest (Baldrian et al. 2010) and a semiarid grassland (Zhou et al. 2013), but a

531 correlation between precipitation with Nmic and Pmic concentrations has not hitherto been

532 reported for natural ecosystems.

533 Furthermore, in the soil community homeostasis analyses, the relationships between $\log C: \mathrm{N}_{R}$

534 and $\log C: N_{B}$, and between $\log C: P_{R}$ and $\log C: P_{B}$ in the $G$ and the RS soils had slopes that did

535 not differ significantly from zero (Figures S1 and S2), suggesting that the soil microbial 
536 communities adjust physiologically (Sinsabaugh \& Follstad Shah 2012) to processing low N and

537 P resources in order to cope with the nutrient limitation, particularly in dry years. Our data also

538 suggest that these physiological adjustments occurred differently in the soil microbial

539 communities of the two vegetation covers and was related to both precipitation quantity and

540 nutrient availability.

541 Our results show how values of TERC:N and TERC:P may shift with respect to variation in

542 annual rainfall and different vegetation cover. The estimated $\mathrm{TER}_{\mathrm{C}: \mathrm{N}}$ was lower in the wet year

543 for both sites, indicating greater sensitivity to $\mathrm{N}$ limitation due to the rapid growth of the

544 microbial community produced by the water availability. For TER $\mathrm{C}_{\mathrm{P} P}$, we observed site-specific

545 differences. The TER $\mathrm{C}_{\mathrm{P}}$ was higher in the RS soil than in the G soil for 2013 and 2014,

546 indicating a greater sensitivity of the microbial community to P limitation in the G soil.

547 However, in order to determine the nutritional limitations of the microbial community, we also

548 compared the estimated TER values and the $\mathrm{C}: \mathrm{N}$ or $\mathrm{C}: \mathrm{P}$ ratios of the organic matter. If the $\mathrm{C}: \mathrm{N}$

549 or C:P ratio of the organic matter being consumed is greater than the TER for that element, this

550 would suggest nutrient limitation (Sterner and Elser, 2002). We observed P limitation in both

551 soils, regardless of year $\left(\mathrm{C}: \mathrm{P}>\mathrm{TER}_{\mathrm{C}: \mathrm{P}} ; \mathrm{p}<0.05\right)$ and $\mathrm{N}$ limitation in the $\mathrm{G}$ soil in the wet year

$552\left(\mathrm{C}: \mathrm{N}=11.3\right.$ and $\left.\mathrm{TER}_{\mathrm{C}: \mathrm{N}}=6 ; \mathrm{p}=0.002\right)$. Our results for the dry year (2012) showed that the

553 ecoenzymatic activities associated with $\mathrm{C}$ and $\mathrm{P}$ acquisition were lowest in the RS and $\mathrm{G}$ soils.

554 Values for TERC:N and TERC:P were similar between the RS and G soils, suggesting that both

555 sites may be vulnerable to drought. However, with the increase of the annual precipitation (years

5562013 and 2014 ), the $\mathrm{G}$ soil microbial community requires more $\mathrm{P}$ and $\mathrm{N}$ to meet its metabolic

557 demands and it makes metabolic adjustments in order to maintain its growth which makes it

558 more susceptible or sensitive to resource limitation. Similarly, increased ecoenzyme activities 
559 associated with $\mathrm{P}$ acquisition and elevated TERC:P values when the water is not limiting (2013

560 and 2014) suggest that the RS soil microbial community is well adapted to acquire P resources

561 via ecoenzyme upregulation post drought.

562 We suggested that, under the scenario proposed by Global Climate Change models for desert

563 ecosystems that predict reduced annual precipitation and increased rainfall variability, the

564 microbial community from both sites could be vulnerable to drought events, but the RS soil

565 microbial communities can make adjustments in order to obtain nutrients in wet years,

566 suggesting that this community is resilient post drought.

567

568 4. Conclusion

569 Soil communities of both sites (RS and G) may be vulnerable to drought. However, the

570 community at the site with lower resources (RS) may have evolved adaptations, such as rapid

571 ecoenzymatic upregulation, under chronic P limitation. This adaptation confers greater resilience

572 within the community to respond to precipitation events post drought. Under the Global Climate

573 Change scenarios for desert ecosystems that predict reduced annual precipitation and an

574 increased intensity and frequency of torrential rains and drought events, soil microbial

575 communities within both sites could be vulnerable to drought through the combination of $\mathrm{C}$ and

576 P co-limitation and reallocation of energy and nutrient resources to physiological acclimatization 577 strategies in order to survive.

578

579 Acknowledgements

580 This paper is presented by Cristina Montiel-González as partial fulfillment of a doctoral degree

581 at the "Programa de Posgrado en Ciencias Biológicas, UNAM". We thank Velazquez-Rodrigo 
582 for his assistance during chemical analyses and Angel Bravo-Monzón for his helpful comments

583 on earlier versions of this manuscript. We thank two anonymous reviewers for comments on a

584 draft of the manuscript.

585

586

\section{REFERENCES}

587

588

589

590

591

592

593

594

595

596

597

598

599

600

601

602

603

604

605

606

607

608

609

610

611

612

613

614

615

616

617

618

619

620

621

Allison SD, and Martiny JBH. 2008. Resistance, resilience, and redundancy in microbial communities. Proceedings of the National Academy of Sciences 105:11512-11519.

Austin AT, Yahdjian L, Stark JM, Belnap J, Porporato A, Norton U, Ravetta DA, and Schaeffer SM. 2004. Water pulses and biogeochemical cycles in arid and semiarid ecosystems. Oecologia 141:221-235.

Baldrian P, Merhautová V, Petránková M, Cajthaml T, and Šnajdr J. 2010. Distribution of microbial biomass and activity of extracellular enzymes in a hardwood forest soil reflect soil moisture content. Applied Soil Ecology 46:177-182.

Bell CW, Acosta-Martinez V, McIntyre NE, Cox S, Tissue DT, and Zak JC. 2009. Linking Microbial Community Structure and Function to Seasonal Differences in Soil Moisture and Temperature in a Chihuahuan Desert Grassland. Microbial Ecology 58:827-842.

Bell CW, Tissue DT, Loik ME, Wallenstein MD, Acosta - Martinez V, Erickson RA, and Zak JC. 2014. Soil microbial and nutrient responses to 7 years of seasonally altered precipitation in a Chihuahuan Desert grassland. Global Change Biology 20:1657-1673.

Berg IA, Kockelkorn D, Ramos-Vera WH, Say RF, Zarzycki J, Hügler M, Alber BE, and Fuchs G. 2010. Autotrophic carbon fixation in archaea. Nat Rev Micro 8:447-460.

Bremmer JM. 1996. Nitrogen-total. In: Sparks D, Page AL, Helmke PA, Loerppert RGH, Soltanpour PN, Tabatabai MA, Jhonson CT, and Sumner ME, eds. Methods of soil analysis part 3: chemical analysis. Madison, USA: Soil Sicence Society of American and American Society of Agronomy, 1085-1121.

Brookes PC, Powlson DS, and Jenkinson DS. 1984. Phosphorus in the soil microbial biomass. Soil Biology and Biochemistry 16:169-175.

Burns R, G. , De Forest J, L. , Marxsen J, Sinsabaugh R, L., Stromberger M, E. , Wallenstein M, D. , Weintraub M, N. , and Zoppini A. 2013. Soil enzymes in a changing environment: Current knowledge and future directions. Soil Biology and Biochemistry 58.

Classen AT, Sundqvist MK, Henning JA, Newman GS, Moore JAM, Cregger MA, Moorhead LC, and Patterson CM. 2015. Direct and indirect effects of climate change on soil microbial and soil microbial-plant interactions: What lies ahead? Ecosphere 6:1-21.

Cleveland CC, and Liptzin D. 2007. C:N:P stoichiometry in soil: is there a "Redfield ratio" for the microbial biomass? Biogeochemistry 85:235-252.

Coleman D, C. , and Whitman W, B. . 2005. Linking species richness, biodiversity and ecosystem function in soil systems. Pedobiologia 49.

Conant RT, Ryan MG, Ågren GI, Birge HE, Davidson EA, Eliasson PE, Evans SE, Frey SD, Giardina CP, Hopkins FM, Hyvönen R, Kirschbaum MUF, Lavallee JM, Leifeld J, Parton WJ, Megan Steinweg J, Wallenstein MD, Martin Wetterstedt JÅ, and Bradford 
MA. 2011. Temperature and soil organic matter decomposition rates - synthesis of current knowledge and a way forward. Global Change Biology 17:3392-3404.

Cregger MA, Schadt CW, McDowell NG, Pockman WT, and Classen AT. 2012. Response of the soil microbial community to changes in precipitation in a semiarid ecosystem. Applied and environmental Microbiology 78:8587-8594.

Chavez-Vergara B, Merino A, Vázquez-Marrufo G, and García-Oliva F. 2014. Organic matter dynamics and microbial activity during decomposition of forest floor under two native neotropical oak species in a temperate deciduous forest in Mexico. Geoderma 235236:133-145.

D'Odorico P, and Bhattachan A. 2012. Hydrologic variability in dryland regions: impacts on ecosystem dynamics and food security. Philosophical Transactions of the Royal Society of London B: Biological Sciences 367:3145-3157.

D'Odorico P, Bhattachan A, Davis KF, Ravi S, and Runyan CW. 2013. Global desertification: Drivers and feedbacks. Advances in Water Resources 51:326-344.

Eivazi F, and Tabatabai MA. 1977. Phosphatases in soils. Soil Biology and Biochemistry 9:167172.

Eivazi F, and Tabatabai MA. 1988. Glucosidases and galactosidases in soils. Soil Biology and Biochemistry 20:601-606.

Ekschmitt K, Liu M, Vetter S, Fox O, and Wolters V. 2005. Strategies used by soil biota to overcome soil organic matter stability — why is dead organic matter left over in the soil? Geoderma 128:167-176.

Elser JJ, Schampel JH, Garcia-Pichel F, Wade BD, Souza V, Eguiarte L, Escalante ANA, and Farmer JD. 2005. Effects of phosphorus enrichment and grazing snails on modern stromatolitic microbial communities. Freshwater Biology 50:1808-1825.

Esch EH, Lipson D, and Cleland EE. 2016. Direct and indirect effects of shifting rainfall on soil microbial respiration and enzyme activity in a semi-arid system. Plant and Soil:1-14.

Evans SE, and Wallenstein MD. 2012. Soil microbial community response to drying and rewetting stress: does historical precipitation regime matter? Biogeochemistry 109:101116.

Farrell M, Prendergast-Miller M, Jones DL, Hill PW, and Condron LM. 2014. Soil microbial organic nitrogen uptake is regulated by carbon availability. Soil Biology and Biochemistry 77:261-267.

Fay PA, Kaufman DM, Nippert JB, Carlisle JD, and Harper CW. 2008. Changes in grassland ecosystem function due to extreme rainfall events: implications for responses to climate change. Global Change Biology 14:1600-1608.

Frost PC, Benstead JP, Cross WF, Hillebrand H, Larson JH, Xenopoulos MA, and Yoshida T. 2006. Threshold elemental ratios of carbon and phosphorus in aquatic consumers. Ecology Letters 9:774-779.

González MF. 2012. Las zonas áridas y semiáridas de México y su vegetación. México, DF: INE-SEMARNAT.

Henry HAL. 2013. Reprint of "Soil extracellular enzyme dynamics in a changing climate". Soil Biology and Biochemistry 56:53-59.

Holmgren M, Stapp P, Dickman CR, Gracia C, Graham S, Gutiérrez JR, Hice C, Jaksic F, Kelt DA, Letnic M, Lima M, López BC, Meserve PL, Milstead WB, Polis GA, Previtali MA, Richter M, Sabaté S, and Squeo FA. 2006. Extreme climatic events shape arid and semiarid ecosystems. Frontiers in Ecology and the Environment 4:87-95. 
668

669

670

671

672

673

674

675

676

677

678

679

680

681

682

683

684

685

686

687

688

689

690

691

692

693

694

695

696

697

698

699

700

701

702

703

704

705

706

707

708

709

710

711

712

Housman DC, Yeager CM, Darby BJ, Sanford Jr RL, Kuske CR, Neher DA, and Belnap J. 2007. Heterogeneity of soil nutrients and subsurface biota in a dryland ecosystem. Soil Biology and Biochemistry 39:2138-2149.

Huffman EWD. 1977. Performance of a new automatic carbon dioxide coulometer. Microchemical Journal 22:567-573.

IPCC. 2013. Climate Change 2013: The Physical Science Basis. Contribution of Working Group I to the Fifth Assessment Report of the Intergovernmental Panel on Climate Change [Stocker,T.F., D. Qin, G.-K. Plattner, M. Tignor, S.K. Allen, J. Boschung, A. Nauels, Y. Xia, V. Bex and P.M. Midgley (eds.)]. Cambridge University Press, Cambridge, United Kingdom and New York, NY, USA. In: Stocker TF, D. Qin, G.-K. Plattner, M. Tignor, S.K. Allen, J. Boschung, A. Nauels, Y. Xia, V. Bex and P.M. Midgley, editor. Cambridge, United Kingdom and New York, NY, USA.

Joergensen RG. 1996. The fumigation-extraction method to estimate soil microbial biomass: Calibration of the kEC value. Soil Biology and Biochemistry 28:25-31.

Joergensen RG, and Mueller T. 1996. The fumigation-extraction method to estimate soil microbial biomass: Calibration of the kEN value. Soil Biology and Biochemistry 28:3337.

Johannes C, and Majcherczyk A. 2000. Laccase activity tests and laccase inhibitors. Journal of Biotechnology 78:193-199.

Jones DL, and Willett VB. 2006. Experimental evaluation of methods to quantify dissolved organic nitrogen (DON) and dissolved organic carbon (DOC) in soil. Soil Biology and Biochemistry 38:991-999.

Jones DL, Willett VB, Stockdale EA, Macdonald AJ, and Murphy DV. 2012. Molecular Weight of Dissolved Organic Carbon, Nitrogen, and Phenolics in Grassland Soils. Soil Science Society of America Journal 76:142-150.

Karl DM. 2014. Microbially mediated transformations of phosphorus in the sea: new views of an old cycle. Annual Review of Marine Science 6:279-337.

Koch IH, Gich F, Dunfield PF, and Overmann J. 2008. Edaphobacter modestus gen. nov., sp. nov., and Edaphobacter aggregans sp. nov., acidobacteria isolated from alpine and forest soils. International Journal of Systematic and Evolutionary Microbiology 58:1114-1122.

Lajtha K, Driscoll TC, Jarrell MW, and Edward TE. 1999. Soil phosphorus: characterization and total element analysis. In: Robertson GP, Coleman CD, Bledsoe SC, and Sollins P, eds. Soil Methods for Long-Term Ecological Research. Oxford University Press, New York LTER, 115-142.

López-Lozano NE, Eguiarte LE, Bonilla-Rosso G, García-Oliva F, Martínez-Piedragil C, Rooks C, and Souza V. 2012. Bacterial Communities and the Nitrogen Cycle in the Gypsum Soils of Cuatro Ciénegas Basin, Coahuila: A Mars Analogue. Astrobiology 12:699-709.

Manzoni S, Schimel JP, and Porporato A. 2012. Responses of soil microbial communities to water stress: results from a meta-analysis. Ecology 93:930-938.

McKee JW, Jones NW, and Long LE. 1990. Stratigraphy and provenance of strata along the San Marcos fault, central Coahuila, Mexico. Geological Society of America Bulletin 102:593614.

Mitsui A, Kumazawa S, Takahashi A, Ikemoto H, Cao S, and Arai T. 1986. Strategy by which nitrogen-fixing unicellular cyanobacteria grow photoautotrophically. Nature 323:720722. 
713

714

715

716

717

718

719

720

721

722

723

724

725

726

727

728

729

730

731

732

733

734

735

736

737

738

739

740

741

742

743

744

745

746

747

748

749

750

751

752

753

754

755

756

757
Moorhead DL, and Sinsabaugh RL. 2006. A THEORETICAL MODEL OF LITTER DECAY AND MICROBIAL INTERACTION. Ecological Monographs 76:151-174.

Moreno B, Cañizares R, Nuñez R, and Benitez E. 2013. Genetic diversity of bacterial $\beta$ glucosidase-encoding genes as a function of soil management. Biology and Fertility of Soils 49:735-745.

Murphy J, and Riley JP. 1962. A modified single solution method for the determination of phosphate in natural waters. Analytica Chimica Acta 27:31-36.

Nemergut DR, Cleveland CC, Wieder WR, Washenberger CL, and Townsend AR. 2010. Plotscale manipulations of organic matter inputs to soils correlate with shifts in microbial community composition in a lowland tropical rain forest. Soil Biology and Biochemistry 42:2153-2160.

Perroni Y, García-Oliva F, and Souza V. 2014a. Plant species identity and soil $\mathrm{P}$ forms in an oligotrophic grassland-desert scrub system. Journal of Arid Environments 108:29-37.

Perroni Y, García-Oliva F, Tapia-Torres Y, and Souza V. 2014b. Relationship between soil P fractions and microbial biomass in an oligotrophic grassland-desert scrub system. Ecological Research 29:463-472.

Philippot L, Bru D, Saby NPA, Čuhel J, Arrouays D, Šimek M, and Hallin S. 2009. Spatial patterns of bacterial taxa in nature reflect ecological traits of deep branches of the $16 \mathrm{~S}$ rRNA bacterial tree. Environmental Microbiology 11:3096-3104.

Schimel J, Balser TC, and Wallenstein M. 2007. Microbial stress-response physiology and its implications for ecosystem function. Ecology 88:1386-1394.

Schimel J, and Schaeffer SM. 2012. Microbial control over carbon cycling in soil. Frontiers in Microbiology 3.

Singh B, Quince C, Macdonald C, Khachane A, Thomas N, Al-Soud W, Sørensen S, He Z, White D, Sinclair A, Crooks B, Zhou J, and Campbell C. 2014. Loss of microbial diversity in soils is coincident with reductions in some specialized functions. Environmental Microbiology.

Sinsabaugh RL. 2010. Phenol oxidase, peroxidase and organic matter dynamics of soil. Soil Biology and Biochemistry 42:391-404.

Sinsabaugh RL, and Follstad Shah JJ. 2011. Ecoenzymatic stoichiometry of recalcitrant organic matter decomposition: the growth rate hypothesis in reverse. Biogeochemistry 102:31-43.

Sinsabaugh RL, and Follstad Shah JJ. 2012. Ecoenzymatic Stoichiometry and Ecological Theory. Annual Review of Ecology, Evolution, and Systematics 43:313-343.

Sinsabaugh RL, Hill BH, and Follstad Shah JJ. 2009. Ecoenzymatic stoichiometry of microbial organic nutrient acquisition in soil and sediment. Nature 462:795-798.

SMATR RDCT. 2007. R: a Language and Environment for Statistical Computing. R Foundation for Statistical Computing, Vienna, ISBN 3-900051-07- 0. URL.

Smith AJ. 1983. Modes of cyanobacterial carbon metabolism. Annales de l'Institut Pasteur / Microbiologie 134:93-113.

Souza V, Siefert JL, Escalante AE, Elser JJ, and Eguiarte LE. 2011. The Cuatro Ciénegas Basin in Coahuila, Mexico: An Astrobiological Precambrian Park. Astrobiology 12:641-647.

Steinweg J, Dukes J, Eldor P, and Wallenstein M. 2013. Microbial responses to multi-factor climate change: effects on soil enzymes. Frontiers in Microbiology 4:146.

Sterner RW, and Elser JJ. 2002. Ecological Stoichiometry: The Biology of Elements from Molecules to the Biosphere: Princeton University Press. 
758

759

760

761

762

763

764

765

766

767

768

769

770

771

772

773

774

775

776

777

778

779

780

781

782

783

784

785

786

787

788

789

790

791

792

793

794

795

796

797

798

799

800

801

T K Kirk a, and Farrell RL. 1987. Enzymatic "Combustion": The Microbial Degradation of Lignin. Annual Review of Microbiology 41:465-501.

Tabatabai MA, and Bremner JM. 1969. Use of p-nitrophenyl phosphate for assay of soil phosphatase activity. Soil Biology and Biochemistry 1:301-307.

Tan H, Barret M, Mooij MJ, Rice O, Morrissey JP, Dobson A, Griffiths B, and O'Gara F. 2013. Long-term phosphorus fertilisation increased the diversity of the total bacterial community and the phoD phosphorus mineraliser group in pasture soils. Biology and Fertility of Soils 49:661-672.

Tanenbaum DM, Goll J, Murphy S, Kumar P, Zafar N, Thiagarajan M, Madupu R, Davidsen T, Kagan L, Kravitz S, Rusch DB, and Yooseph S. 2010. The JCVI standard operating procedure for annotating prokaryotic metagenomic shotgun sequencing data. Standards in Genomic Sciences 2:229-237.

Tapia-Torres Y, Elser JJ, Souza V, and García-Oliva F. 2015a. Ecoenzymatic stoichiometry at the extremes: How microbes cope in an ultra-oligotrophic desert soil. Soil Biology and Biochemistry 87:34-42.

Tapia-Torres Y, López-Lozano NE, Souza V, and García-Oliva F. 2015b. Vegetation-soil system controls soil mechanisms for nitrogen transformations in an oligotrophic Mexican desert. Journal of Arid Environments 114:62-69.

Tapia-Torres Y, Rodríguez-Torres MD, Elser JJ, Islas A, Souza V, García-Oliva F, and OlmedoÁlvarez G. 2016. How to live with phosphorus scarcity in soil and sediment: Lessons from bacteria. Applied and environmental Microbiology.

Technicon. 1977. Technicon Industrial System. Method No. 329-74 W/B Individual/simultaneous determinations of nitrogen and/or phosphorus in $\mathrm{BD}$ acid giest. Analytical Chemistry 49:427A-427A.

Thibault KM, and Brown JH. 2008. Impact of an extreme climatic event on community assembly. Proceedings of the National Academy of Sciences 105:3410-3415.

Thomey ML, Collins SL, Vargas R, Johnson JE, Brown RF, Natvig DO, and Friggens MT. 2011. Effect of precipitation variability on net primary production and soil respiration in a Chihuahuan Desert grassland. Global Change Biology 17:1505-1515.

Tiessen H, and Moir JO. 2008. Characterization of available P by sequential extraction. In: Carter MR, and Gregorich EG, eds. Soil sampling and methods of analysis. Second Edition ed. Boca Raton Fl USA: CRC Press, 293-306.

Turner BL, Mahieu N, and Condron LM. 2003. Phosphorus-31 Nuclear Magnetic Resonance Spectral Assignments of Phosphorus Compounds in Soil NaOH-EDTA Extracts. Soil Science Society of America Journal 67:497-510.

Vance ED, Brookes PC, and Jenkinson DS. 1987. An extraction method for measuring soil microbial biomass C. Soil Biology and Biochemistry 19:703-707.

Verchot LV, and Borelli T. 2005. Application of para-nitrophenol (pNP) enzyme assays in degraded tropical soils. Soil Biology and Biochemistry 37:625-633.

Von Ende NC. 2001. Repeated-measures Analysis. In: Scheiner MS, and Gurevitch J, eds. Desing and Analysis of Ecological Experiments. Second Edition ed. New York: Oxford University Press, 134-157.

Waldrop MP, Balser TC, and Firestone MK. 2000. Linking microbial community composition to function in a tropical soil. Soil Biology and Biochemistry 32:1837-1846. 
802

803

804

805

806

807

808

809

810

811

812

813

814

815

816

817

818

819

Wallenstein MD, and Hall EK. 2012. A trait-based framework for predicting when and where microbial adaptation to climate change will affect ecosystem functioning. Biogeochemistry 109:35-47.

Waring BG, Weintraub SR, and Sinsabaugh RL. 2014. Ecoenzymatic stoichiometry of microbial nutrient acquisition in tropical soils. Biogeochemistry 117:101-113.

Xie G, Bruce DC, Challacombe JF, Chertkov O, Detter JC, Gilna P, Han CS, Lucas S, Misra M, Myers GL, Richardson P, Tapia R, Thayer N, Thompson LS, Brettin TS, Henrissat B, Wilson DB, and McBride MJ. 2007. Genome Sequence of the Cellulolytic Gliding Bacterium Cytophaga hutchinsonii. Applied and environmental Microbiology 73:35363546.

Zechmeister-Boltenstern S, Keiblinger KM, Mooshammer M, Peñuelas J, Richter A, Sardans J, and Wanek W. 2015. The application of ecological stoichiometry to plant-microbial-soil organic matter transformations. Ecological Monographs 85:133-155.

Zhou X, Chen C, Wang Y, Xu Z, Duan J, Hao Y, and Smaill S. 2013. Soil extractable carbon and nitrogen, microbial biomass and microbial metabolic activity in response to warming and increased precipitation in a semiarid Inner Mongolian grassland. Geoderma 206:2431. 


\section{Table $\mathbf{1}$ (on next page)}

\section{Table 1}

Means and (standard errors) of soil nutrients and ratios in the rosetophylous scrub (RS) and grassland (G) soils over three consecutive years (2012, 2013 and 2014) in the Cuatro Ciénegas Basin, Coahuila, Mexico. Different uppercase letters $(A$ and $B)$ indicate significantly different means $(P<0.05)$ between vegetation cover types (rosetophylous scrub and grassland) within the same sampling year (2012, 2013 and 2014); whereas different lowercase letters $(a, b$ and $c)$ indicate significantly different means $(P<0.05)$ among sampling dates within the same site. 
1 Table 1. Means and (standard errors) of soil nutrients and ratios in the rosetophylous scrub (RS) 2 and grassland $(\mathrm{G})$ soils over three consecutive years (2012, 2013 and 2014) in the Cuatro 3 Ciénegas Basin, Coahuila, Mexico. Different uppercase letters (A and B) indicate significantly 4 different means $(\mathrm{P}<0.05)$ between vegetation cover types (rosetophylous scrub and grassland) 5 within the same sampling year (2012, 2013 and 2014); whereas different lowercase letters (a, b 6 and $\mathrm{c})$ indicate significantly different means $(\mathrm{P}<0.05)$ among sampling dates within the same 7 site.

8

\begin{tabular}{|c|c|c|c|c|c|c|}
\hline & \multicolumn{6}{|c|}{ Year } \\
\hline & \multicolumn{2}{|c|}{2012} & \multicolumn{2}{|c|}{2013} & \multicolumn{2}{|c|}{2014} \\
\hline & $\mathrm{RS}$ & $\mathrm{G}$ & $\mathrm{RS}$ & $\mathrm{G}$ & $\mathrm{RS}$ & $\mathrm{G}$ \\
\hline Moisture (\%) & $\begin{array}{l}12.7 \\
(1.1)^{\mathrm{Bc}}\end{array}$ & $\begin{array}{l}24.6 \\
(2.5)^{\mathrm{Ab}}\end{array}$ & $24.6(3)^{\mathrm{Bab}}$ & $\begin{array}{l}43.5 \\
(1.3)^{\mathrm{Aa}}\end{array}$ & $\begin{array}{l}16.4(1.0)^{\mathrm{B}} \\
\mathrm{b}\end{array}$ & $\begin{array}{l}37.1(7.1) \\
\text { Aa }\end{array}$ \\
\hline $\mathrm{pH}$ & $\begin{array}{l}8.5(0.06) \\
\mathrm{Aa}\end{array}$ & $\begin{array}{l}8.3 \\
(0.04)^{\mathrm{Ba}}\end{array}$ & $\begin{array}{l}8.1 \\
(0.03)^{\mathrm{Ab}}\end{array}$ & $\begin{array}{l}8.1 \\
(0.02)^{\mathrm{Ab}}\end{array}$ & $\begin{array}{l}8.1 \\
(0.02)^{\mathrm{Ab}}\end{array}$ & $\begin{array}{l}8.1 \\
(0.1)^{\mathrm{Aab}}\end{array}$ \\
\hline \multicolumn{7}{|c|}{ Dissolved organic nutrient concentration } \\
\hline $\mathrm{DOC}\left(\mu \mathrm{g} \mathrm{g}^{-1}\right)$ & $9(1)^{\mathrm{Ab}}$ & $19(4)^{\mathrm{Ac}}$ & $23(4)^{\mathrm{Ba}}$ & $52(1)^{\mathrm{Ab}}$ & $28(2)^{\mathrm{Ba}}$ & $67(4)^{\mathrm{Aa}}$ \\
\hline $\mathrm{DON}\left(\mu \mathrm{g} \mathrm{g}^{-1}\right)$ & $4.1(0.5)^{\mathrm{Bb}}$ & $7.0(0.6)^{\mathrm{Ab}}$ & $\begin{array}{l}5.5 \\
(0.5)^{\mathrm{Bab}}\end{array}$ & $\begin{array}{l}10.8 \\
(0.8)^{\mathrm{Aa}}\end{array}$ & $6.9(0.3)^{\mathrm{Ba}}$ & $\begin{array}{l}7.8 \\
(0.4)^{\mathrm{Aab}}\end{array}$ \\
\hline $\mathrm{DOP}\left(\mu \mathrm{g} \mathrm{g}^{-1}\right)$ & $1.2(0.2)^{\mathrm{Ab}}$ & $0.3(0.3)^{\mathrm{Ab}}$ & $2.8(0.2)^{\mathrm{Ba}}$ & $5.1(0.2)^{\mathrm{Aa}}$ & $2.8(0.2)^{\mathrm{Ba}}$ & $5.3(0.5)^{\mathrm{Aa}}$ \\
\hline DOC:DON & $2.3(0.6)$ & $3.1(0.6)$ & $4.2(0.6)$ & $4.9(0.6)$ & $4.0(0.6)$ & $6.8(0.6)$ \\
\hline DOC:DOP & $7.9(3.6)$ & $15.3(3.6)$ & $8.2(1.3)$ & $18.8(1.3)$ & $10.3(1.2)$ & $13.0(1.1)$ \\
\hline DON:DOP & $3.6(0.4)$ & $6.8(3.3)$ & $2.0(0.1)$ & $2.1(0.1)$ & $2.6(0.4)$ & $1.5(0.1)$ \\
\hline \multicolumn{7}{|c|}{ Available nutrient concentration } \\
\hline $\mathrm{NH}_{4}{ }^{+}\left(\mu \mathrm{g} \mathrm{g}^{-1}\right)$ & $2.8(0.2)^{\mathrm{Ba}}$ & $6.3(0.5)^{\mathrm{Ac}}$ & $3.6(0.2)^{\mathrm{Ba}}$ & $\begin{array}{l}11.8 \\
(1.1)^{\mathrm{Aa}}\end{array}$ & $2.7(0.4)^{\mathrm{Ba}}$ & $\begin{array}{l}8.9 \\
(0.2)^{\mathrm{Ab}}\end{array}$ \\
\hline $\mathrm{NO}_{3}^{-}\left(\mu \mathrm{g} \mathrm{g}^{-1}\right)$ & $\begin{array}{l}10.4 \\
(1.4)^{\mathrm{Aa}}\end{array}$ & $6.7(1.4)^{\mathrm{Ba}}$ & $1.7(0.3)^{\mathrm{Ab}}$ & $\begin{array}{l}3.2 \\
(0.4)^{\mathrm{Aab}}\end{array}$ & $1.7(0.1)^{\mathrm{Ab}}$ & $1.0(0.1)^{\mathrm{Ab}}$ \\
\hline $\mathrm{Pi}\left(\mu \mathrm{g} \mathrm{g}^{-1}\right)$ & $1.9(0.2)$ & $2.5(0.2)$ & $2.9(0.4)$ & $4.5(0.4)$ & $3.9(0.6)$ & $5.3(0.6)$ \\
\hline
\end{tabular}

9 DOC: dissolved organic carbon; DON: dissolved organic nitrogen; DOP: dissolved organic 10 phosphorus; $\mathrm{NH}_{4}^{+}$: available ammonium; $\mathrm{NO} 3$ : available nitrate; Pi: Available inorganic 11 phosphorus.

12 


\section{Table 2 (on next page)}

Table 2

F-ratios and significant levels of the repeated-measures ANOVA for soil variables quantified in the rosetophylous scrub and grassland soils over three consecutive years (2012, 2013 and 2014) in Cuatro Ciénegas Basin, Coahuila Mexico. 
1 Table 2. F-ratios and significant levels of the repeated-measures ANOVA for soil variables

2 quantified in the rosetophylous scrub and grassland soils over three consecutive years (2012,

32013 and 2014) in Cuatro Ciénegas Basin, Coahuila Mexico.

\begin{tabular}{lccc}
\hline & \multicolumn{3}{c}{ Source of variation } \\
\cline { 2 - 4 } Parameters & Between subjects & \multicolumn{2}{c}{ Within subjects } \\
\cline { 2 - 4 } & Vegetation cover & Year & Vegetation cover X Year \\
\hline Moisture & $90.7(<0.0001)$ & $49.1(<0.0001)$ & $2.7(0.08)$ \\
pH & $7.3(0.02)$ & $28.0(<0.0001)$ & $5.4(0.01)$ \\
& \multicolumn{1}{c}{ Dissolved nutrients } & \\
DOC & $102.1(<0.0001)$ & $79.2(<0.0001)$ & $14.5(<0.0001)$ \\
DON & $38.5(<0.0001)$ & $25.1(<0.0001)$ & $3.8(0.03)$ \\
DOP & $14.1(0.002)$ & $55.0(<0.0001)$ & $13.2(0.0001)$ \\
DOC:DON & $6.4(0.02)$ & $11.6(0.0002)$ & $2.0(0.1)$ \\
DOC:DOP & $9.1(0.01)$ & $0.5(0.6)$ & $1.8(0.2)$ \\
DON:DOP & $1.8(0.2)$ & $3.0(0.07)$ & $1.2(0.3)$ \\
& Available nutrients & \\
$\mathrm{NH}_{4}{ }^{+}$ & $236.8(<0.0001)$ & $19.0(<0.000)$ & $10.5(0.0005)$ \\
$\mathrm{NO}_{3}{ }^{-}$ & $1.8(0.1)$ & $47(<0.0001)$ & $5.4(0.01)$ \\
$\mathrm{Pi}^{\mathrm{DOC}}$ & $14.2(0.003)$ & $12.9(0.002)$ & $1.1(0.3)$ \\
\hline
\end{tabular}

4 DOC: dissolved organic carbon; DON: dissolved organic nitrogen; DOP: dissolved organic 5 phosphorus; $\mathrm{NH}_{4}^{+}$: available ammonium; $\mathrm{NO}_{3}{ }^{-}$: available nitrate; Pi: Available inorganic 6 phosphorus. 


\section{Table 3 (on next page)}

Table 3

Means and (standard errors) of microbial biomass nutrients, and microbial nutrient ratios in the rosetophylous scrub (RS) and the grassland (G) soils over three consecutive years (2012, 2013 and 2014) in the Cuatro Ciénegas Basin, Coahuila, Mexico. Different uppercase letter (A and $B$ ) indicate that means differ significantly $(P<0.05)$ between vegetation cover types (RS and G) within the same sampling year (2012, 2013 and 2014); whereas different lowercase letters $(a, b$ and $c)$ indicate significantly different means $(P<0.05)$ among sampling dates within the same site. 
1 Table 3. Means and (standard errors) of microbial biomass nutrients, and microbial nutrient 2 ratios in the rosetophylous scrub (RS) and the grassland $(\mathrm{G})$ soils over three consecutive years 3 (2012, 2013 and 2014) in the Cuatro Ciénegas Basin, Coahuila, Mexico. Different uppercase 4 letter $(\mathrm{A}$ and $\mathrm{B})$ indicate that means differ significantly $(\mathrm{P}<0.05)$ between vegetation cover 5 types (RS and G) within the same sampling year (2012, 2013 and 2014); whereas different 6 lowercase letters $(\mathrm{a}, \mathrm{b}$ and $\mathrm{c})$ indicate significantly different means $(\mathrm{P}<0.05)$ among sampling 7 dates within the same site.

\begin{tabular}{|c|c|c|c|c|c|c|}
\hline & \multicolumn{6}{|c|}{ Year } \\
\hline & \multicolumn{2}{|c|}{2012} & \multicolumn{2}{|c|}{2013} & \multicolumn{2}{|c|}{2014} \\
\hline & $\mathrm{RS}$ & $\mathrm{G}$ & $\mathrm{RS}$ & $\mathrm{G}$ & $\mathrm{RS}$ & $\mathrm{G}$ \\
\hline \multicolumn{7}{|c|}{ Nutrients concentration within microbial biomass } \\
\hline Cmic $\left(\mu \mathrm{g} \mathrm{g}^{-1}\right)$ & $68(12)$ & $93(12)$ & $191(20)$ & $289(20)$ & $287(16)$ & $379(1)$ \\
\hline $\operatorname{Nmic}\left(\mu \mathrm{g} \mathrm{g}^{-1}\right)$ & $\begin{array}{l}4.2 \\
(0.6)^{\mathrm{Ab}}\end{array}$ & $6.4(0.6)^{\mathrm{Ac}}$ & $\begin{array}{l}10.0 \\
(1.0)^{\mathrm{Bb}}\end{array}$ & $\begin{array}{l}22.0 \\
(2.8)^{\mathrm{Ab}}\end{array}$ & $\begin{array}{l}42.2 \\
(1.7)^{\mathrm{Ba}}\end{array}$ & $\begin{array}{l}59.8 \\
(1.9)^{\mathrm{Aa}}\end{array}$ \\
\hline $\operatorname{Pmic}\left(\mu \mathrm{g} \mathrm{g}^{-1}\right)$ & $\begin{array}{l}2.3 \\
(0.6)^{\mathrm{Aa}}\end{array}$ & $2.5(1.3)^{\mathrm{Ab}}$ & $2.4(0.1)^{\mathrm{Ba}}$ & $6.4(0.6)^{\mathrm{Aa}}$ & $\begin{array}{l}2.2 \\
(0.02)^{\mathrm{Ba}}\end{array}$ & $6.1(0.4)^{\mathrm{Aa}}$ \\
\hline Cmic:Nmic & $20(4)$ & $15(4)$ & $20(2)$ & $14(2)$ & $7(0.3)$ & $6(0.3)$ \\
\hline Cmic:Pmic & $17(5)^{\mathrm{Ac}}$ & $9(5)^{\mathrm{Ac}}$ & $79(6)^{\mathrm{Ab}}$ & $48(6)^{\mathrm{Bb}}$ & $\begin{array}{l}127 \\
(0.2)^{\mathrm{Aa}}\end{array}$ & $63(4)^{\mathrm{Ba}}$ \\
\hline Nmic:Pmic & $\begin{array}{l}0.9 \\
(0.3)^{\mathrm{Ac}}\end{array}$ & $0.4(0.2)^{\mathrm{Ac}}$ & $4.2(0.4)^{\mathrm{Ab}}$ & $3.6(0.6)^{\mathrm{Ab}}$ & $\begin{array}{l}18.7 \\
(0.8)^{\mathrm{Aa}}\end{array}$ & $\begin{array}{l}10.1 \\
(0.7)^{\mathrm{Ba}}\end{array}$ \\
\hline
\end{tabular}

8

9 Cmic: microbial carbon; Nmic: microbial nitrogen; Pmic: microbial phosphorus. 


\section{Table 4 (on next page)}

Table 4

F-ratios and significant levels of the repeated measures ANOVA for microbial nutrient concentration, microbial nutrient ratios and specific enzymatic activity quantified in the rosetophylous scrub (RS) and the grassland (G) soils over three consecutive years (2012, 2013 and 2014) in Cuatro Ciénegas Basin, Coahuila Mexico. 
1 Table 4. F-ratios and significant levels of the repeated measures ANOVA for microbial nutrient

2 concentration, microbial nutrient ratios and specific enzymatic activity quantified in the

3 rosetophylous scrub (RS) and the grassland $(\mathrm{G})$ soils over three consecutive years $(2012,2013$

4 and 2014) in Cuatro Ciénegas Basin, Coahuila Mexico.

\begin{tabular}{|c|c|c|c|}
\hline \multirow{3}{*}{ Parameters } & \multicolumn{3}{|c|}{ Source of variation } \\
\hline & \multirow{2}{*}{$\begin{array}{l}\text { Between subject } \\
\text { Vegetation cover }\end{array}$} & \multicolumn{2}{|c|}{ Within subjects } \\
\hline & & Year & Vegetation cover X Year \\
\hline \multicolumn{4}{|c|}{ Dissolved nutrients } \\
\hline Cmic & $62.1(<0.0001)$ & $93.3(<0.0001)$ & $2.3(0.11)$ \\
\hline Nmic & $48.7(<0.0001)$ & $484(<0.0001)$ & $12.9(0.0001)$ \\
\hline Pmic & $24.6(0.0003)$ & $5.8(0.008)$ & $5.7(0.009)$ \\
\hline Cmic:Nmic & $4.0(0.07)$ & $12.3(0.0002)$ & $0.7(0.5)$ \\
\hline Cmic:Pmic & $107(<0.0001)$ & $92(<0.0001)$ & $11(0.0005)$ \\
\hline Nmic:Pmic & $42(<0.0001)$ & $316(<0.0001)$ & $34(<0.0001)$ \\
\hline \multicolumn{4}{|c|}{ Specific enzymatic activity } \\
\hline BG & $1.2(0.28)$ & $22.8(<0.0001)$ & $1.1(0.33)$ \\
\hline $\mathrm{CBH}$ & $3(0.1)$ & $9.9(<0.0001)$ & $0.2(0.7)$ \\
\hline NAG & $8.1(0.01)$ & $52(<0.0001)$ & $10.8(<0.0001)$ \\
\hline PPO & $8.8(0.011)$ & $34(<0.0001)$ & $4(0.03)$ \\
\hline PME & $137(<0.0001)$ & $444(<0.0001)$ & $80(<0.0001)$ \\
\hline PDE & $67(<0.0001)$ & $232(<0.0001)$ & $19(<0.0001)$ \\
\hline
\end{tabular}

5

6 Cmic: microbial carbon; Nmic: microbial nitrogen; Pmic: microbial phosphorus; BG: $\beta$-1,4-

7 glucosidase; $\mathrm{CBH}$ : cellobiohydrolase; NAG: $\beta-1,4-\mathrm{N}$-acetylglucosaminidase; PPO: polyphenol

8 oxidase; PME: phosphomonoesterase; PDE: phosphodiesterase 


\section{Figure 1 (on next page)}

Simple linear regressions between annual accumulated precipitation before the sampling date for four years and nutrients immobilized by microbial biomass for RS soil and $\mathrm{G}$ soil.

The dotted line represents the standard deviation at 0.95 . 
Figure 2 (on next page)

Simple linear regressions between the annual accumulated precipitation before the sampling date for four years and ratios of nutrients immobilized by microbial biomass for RS soil and G soil. 



\section{Figure 3 (on next page)}

\section{Specific enzymatic activity}

Specific enzymatic activity of: (A) $\beta-1,4-$ glucosidase (BG), (B) cellobiohydrolase (CBH), (C) polyphenol oxidase (PPO), (D) $\beta$-1,4-N-acetylglucosaminidase (NAG), (E) phosphomonoesterase (PME) and (F) phosphodiesterase (PDE) in the rosetophylous scrub (RS) and grassland (G) soils over three consecutive years (2012, 2013 and 2014) in the Cuatro Ciénegas Basin, Coahuila, Mexico. Different uppercase letters (A and $B$ ) indicate significantly different means $(P<0.05)$ between vegetation cover types (RS and $G)$ within the same sampling year (2012, 2013 and 2014); whereas different lowercase letters ( $a, b$ and $c$ ) vertically indicate significantly different means $(P<0.05)$ among sampling dates within the same site. 

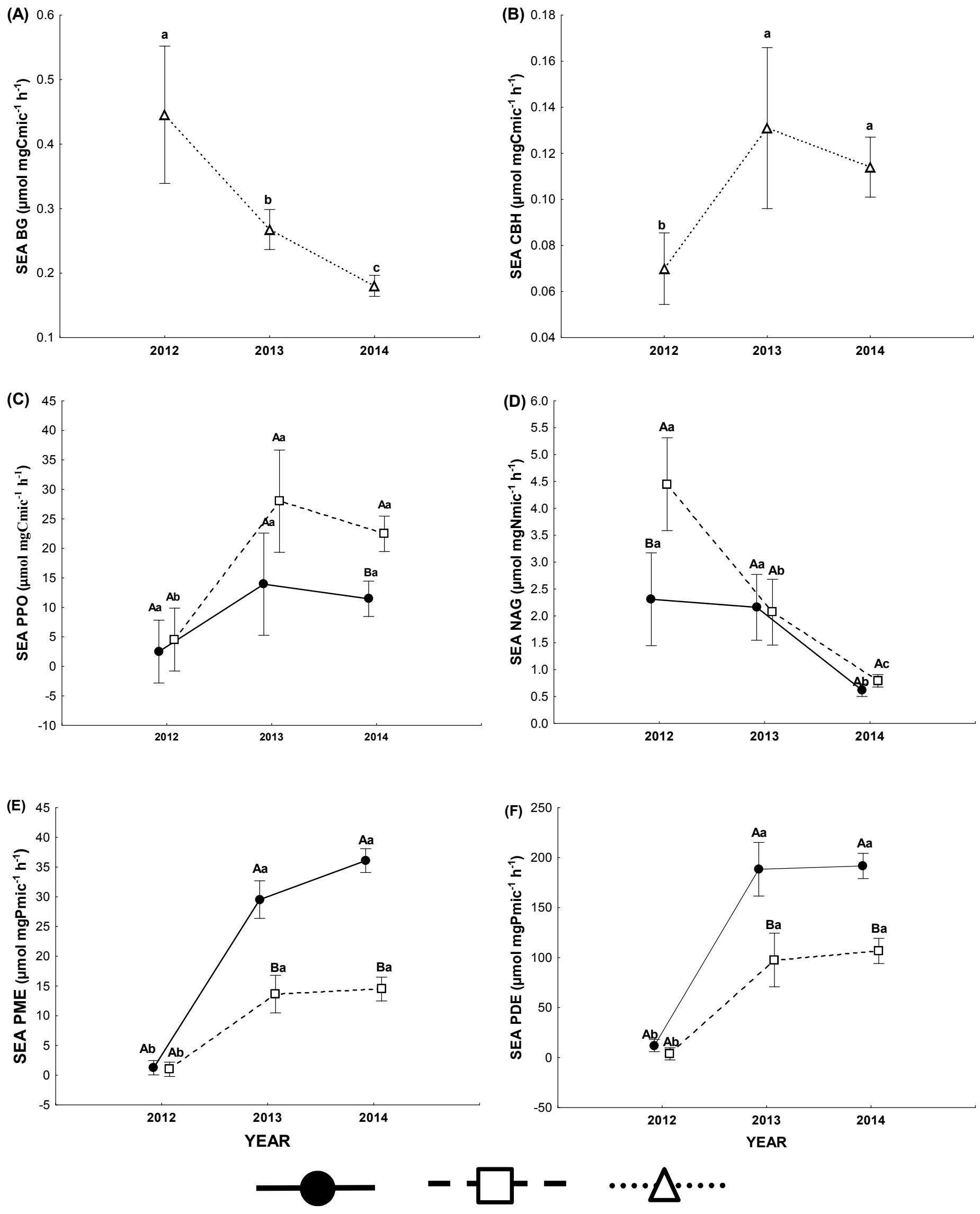

RS

G

SA 
Figure 4(on next page)

Taxonomic distribution of sequences obtained from Pyrosequencing of 16S rRNA tags of rosetophylous scrub and grassland soils during a wet year (2010). 


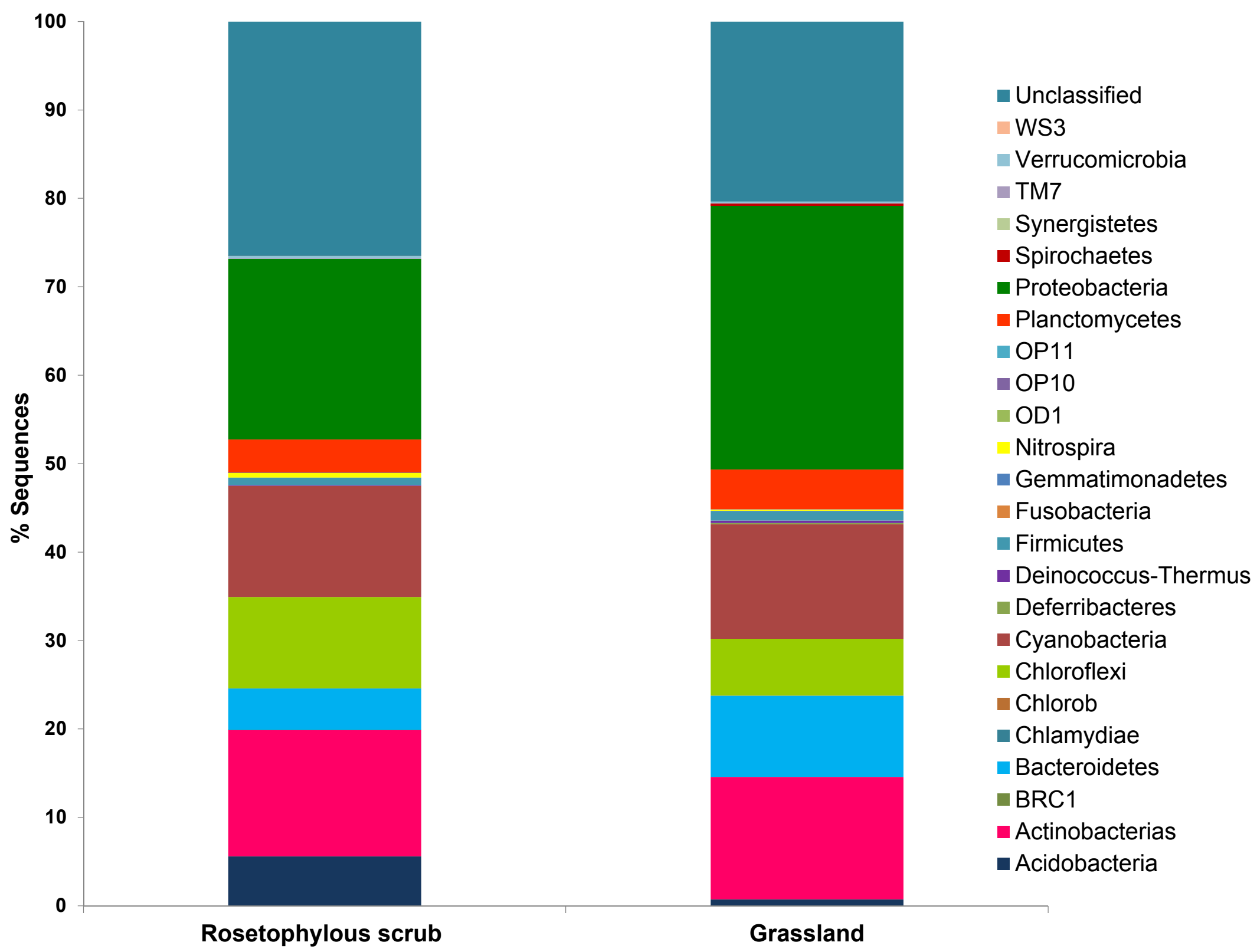


Figure $\mathbf{5}$ (on next page)

Threshold Elemental Ratio C:N and C:P ( $A$ and $B$, respectively) of the soil microbial community over three consecutive years (2012, 2013 and 2014. 
A)

\section{n Rosetophylous scrub Grassland}

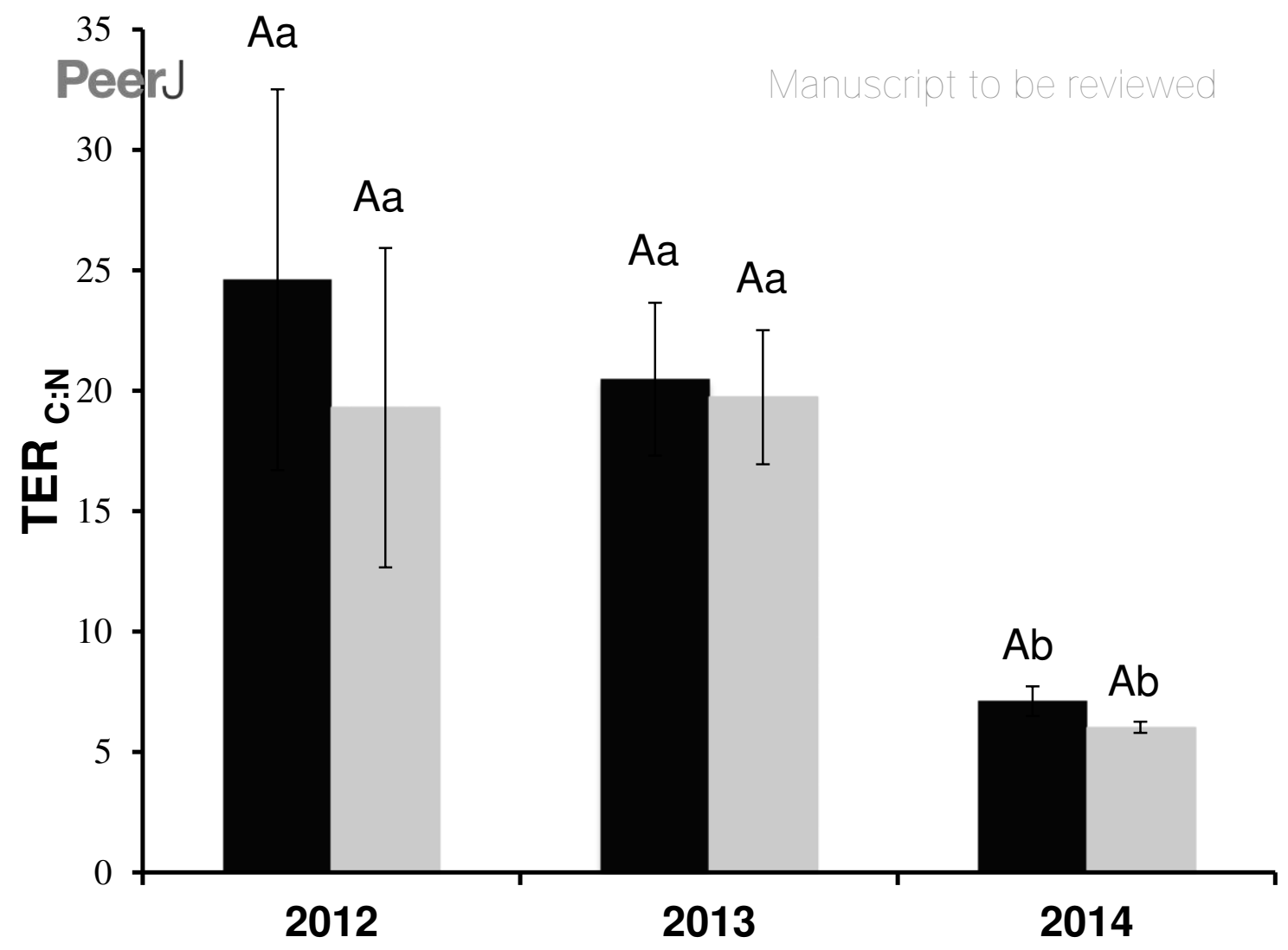

B)

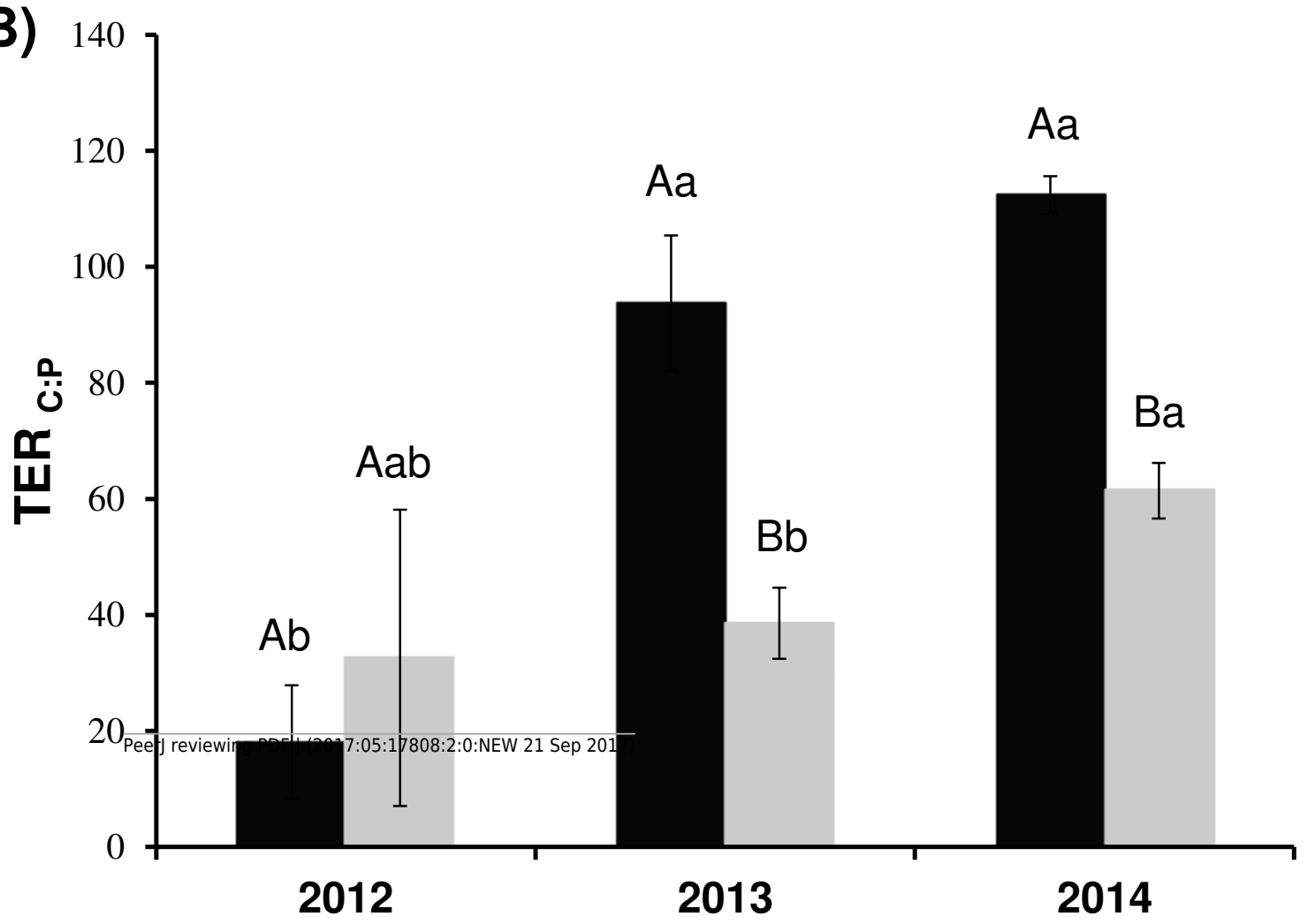

